\title{
Relational Categorization: Evidence from the Diversification of American Labor Unions
}

\begin{abstract}
This article draws upon the changes in voting patterns for American labor unions in recent decades to extend organizational theory about how categorization systems are reproduced and break down. Recent categorization research emphasizes cognitive mechanisms for the reproduction of category schemes: actors explicitly evaluate organizations against an ideal set of categories. This article argues that category schemes can also be reproduced as the epiphenomena of stable social interactions. Such "relational" mechanisms are particularly useful for understanding why specialized organizations sometimes manage to diversify, despite having similar audiences. When stable patterns of social interaction are disrupted, category schemes that were reproduced by such interactions quickly fall apart. Predictions based on this theory are tested on the attempts by American labor unions to diversify their memberships between 1961 and 1999. Consistent with the theory, workers after the early 1980s came to vote for unions that diversified their organizing across industries, but only if those unions had adopted organizational reforms consistent with those described in recent literature on labor-union revitalization. The interaction between such revitalization attempts by individual unions and the strength of union jurisdiction is explored using a combination of interviews with current and former union staff and organizers, and quantitative analysis of four decades' organizing drives.
\end{abstract}




\section{Introduction}

American labor unions have been a laboratory for theories of organizational change. Few other organizations, once so well established, have faced such severe challenges to their legitimacy and survival. And few other organizations, once so set in their ways, have tried so hard to change their strategies and tactics. Sociologists exploring the prospects for laborunion revitalization have documented how labor unions changed their procedures both for bargaining with employers and for recruiting new members. This work has shown how social movements can influence formal organizations (Isaac, McDonald \& Lukasik 2006, Warren \& Bronfenbrenner 2007); demonstrated how those organizations can draw inspiration and techniques from social movements (Ganz 2000, Clawson 2003); and reconsidered the inevitability of oligarchy in formal organizations (Voss \& Sherman 2000, Martin 2007, Yu 2008). Unions in crisis have led sociologists to integrate the study of the labor movement more tightly with organizational theory than unions in happier times ever did.

There are nonetheless aspects of labor's transformation that have received little attention. For example, the reforms of the union-organizing process that many researchers have documented have occurred alongside the breakdown of the unions' older system of exclusive jurisdictions. Many organizing drives of the last two decades have involved unions targeting workers in industries where they had little presence. Longshoremen have organized bicycle messengers (SFBMA 1998, SFBMA 2000); Autoworkers have organized legal clerks; Communications Workers have organized adjunct faculty (UCW-CWA 2002). We know less today about what work a union member does, based on what union they belong to, than we did in the past; and labor scholars who describe the rise of such "conglomerate unions" (Lichtenstein 2002) have suggested that this shift is more pronounced in the more "revitalized" parts of the labor movement.

The weakening of union jurisdiction is a puzzle for organization theorists, especially given recent theory on how social categorization systems constrain organizations and penalize

"boundary-spanners" (Zuckerman 1999, Zuckerman 2000, Hannan, Pólos \& Carroll 2007, Ne- 
gro, Koçak \& Hsu 2010). That work emphasizes how the audiences upon which organizations rely for support and resources use systems of categories to make sense of a complex reality and to decide which organizations are worthy of comparison and evaluation. Because organizations that do multiple, possibly unrelated things are both harder to make sense of (Hsu 2006) and offer a less-clear value proposition (Zuckerman 1999, Zuckerman 2003) than organizations that are specialized, audiences give less support to generalists than to specialists. In diverse empirical settings, ranging from securities (Zuckerman 1999) and film (Hsu 2006) to online auctions (Hsu, Hannan \& Koçak 2009, Leung \& Sharkey 2010), venture capital (Wu \& Dokko 2009) and broadcast television (Perretti, Negro \& Lomi 2008), researchers have documented an isomorphism between audiences' categories and organizations' specializations.

Historically, the labor movement had many of the features that social categorization theory emphasizes. Unions carved up the economy into a set of exclusive industrial jurisdictions. Those jurisdictions had normative value: that the term "raid" is used to refer to one union's organizing in another's jurisdiction is telling. And audiences-potential union membersreinforced those jurisdictions. All else equal, a union raid was less likely to succeed than a typical organizing drive (Krislov 1954, Barbash 1983, Pawlenko 2005). Unions that tried to span the boundaries of jurisdiction received fewer votes from potential members. Were we to look at American unions before about 1980, we might tally them as another setting in which the constraining effects of categorization were at play. Yet after 1980, that jurisdictional system seemed to fall apart. Was the historical resemblance merely a fluke? Or can the collapse of union jurisdiction, and the revitalization efforts that accompanied it, enrich organization theory's understanding of how category systems operate in social life?

The key question is not why unions would want to enroll workers from new and different industries. We know from industrial-relations research specifically and organizational theory more generally why organizations whose bases of support are shrinking would try to diversify. The question is why potential union members would be more likely to vote for diversified 
unions than they had in the past.

In this article, I explore the impact of union revitalization efforts on labor's old jurisdictional system. Drawing upon interviews with union officials and current and former organizers, I show that the jurisdictional system did constrain unions' and workers' behavior in the past, but not through the mechanism that most recent work on categorization emphasizes. Specifically, most categorization research stresses the cognitive process of evaluating organizations relative to one another against an ideal set, or scheme, of categories (Hannan, Pólos \& Carroll 2007, Negro, Koçak \& Hsu 2010). Yet workers rarely devoted any serious cognitive attention to the jurisdiction system as such, and rarely made explicit comparisons between more- and less-diversified unions. Instead, referrals by already-organized workers and contacts with local union business agents funneled workers into the pre-existing jurisdictions. The jurisdictional system was reproduced as an epiphenomenon of the stable, patterned interactions of the parties involved. The reproductive mechanism of union categories, in other words, was relational rather than cognitive. Some early work on categorization suggested that the structure of social relations supported category schemes alongside cognition (Zuckerman 1999), but subsequent work has not developed this idea. Yet in cases such as the labor movement, relational mechanisms are more useful than cognitive mechanisms for understanding how jurisdictions were reproduced.

This relational mechanism also helps explain how jurisdiction broke down. As union density declined in the face of an increasingly strong employer offensive (Goldfield 1987, Freeman \& Kleiner 1990, Farber \& Western 2002, Tope \& Jacobs 2009), the historical pattern of interaction between unions and workers also collapsed. Many unions explicitly adopted new tactics for contacting and recruiting workers, as much of the revitalization literature has documented (Bronfenbrenner 1998, Voss \& Sherman 2000, Milkman \& Voss 2004, Fantasia \& Voss 2004, Martin 2007). Based on that work and again drawing on interviews with organizers, I underline that the new organizing strategies adopted by some unions rely on organizers and tactics that prize developing new relationships with workers in previously- 
ignored parts of the economy. Workers have increasingly lent their support to unions that use these tactics. An unintended effect of this shift down at the level of the organizing drive is that the epiphenomenon of jurisdiction has faded in importance.

The decay of union jurisdiction has important implications for how category systems are reproduced and transformed. Yet it also provides a test for some of the implications of laborunion revitalization work on a larger scale than has been done. Most revitalization research has relied on case studies and interviews with union officials and organizers (Voss \& Sherman 2000, Clawson 2003, Rooks 2004). For unpacking the details of a process as complicated as organizational transformation, this approach is invaluable. However, the level of detail that such studies have gathered is extremely difficult to reproduce with representative organizing data. I propose here that, if theories of labor-union revitalization are correct, then unions that have made structural reforms in line with revitalization should face less resistance when they try to organize more diverse groups of workers. I test this association using nationally representative data on union organizing drives between 1961 and 1999 and find support for such a relationship. In sum, I suggest that the interplay between union-revitalization and organization theory, so fruitful in the past, can yet be pushed forward: the former by suggesting new and different mechanisms, and the latter by suggesting testable hypotheses.

The rest of this article is organized as follows. In the next section I flesh out the distinction between cognitive and relational mechanisms and tie that distinction to other parts of social theory. I then describe the empirical context of jurisdiction in labor organizing. My goal in doing so is neither to theorize labor's collapse nor its isolated successes; I take for granted for example that organizing tactics pioneered by unions like the SEIU and later adopted by other unions have been disproportionately effective at winning employer neutrality in many organizing campaigns (Milkman \& Voss (2004) review much of this research). Instead I point out the implications of these developments for union jurisdiction. As a test of whether the changed patterns of interaction in union organizing helped weaken union jurisdictions, I present models of organizing-drive success that are partial functions of how diverse a union's 
organizing is, whether the union has adopted structural reforms like those described in the revitalization research, and the number of other unions who have adopted similar reforms. The latter I use to track the shift in "cultural expectations" within the labor movement, which Voss \& Sherman (2000, p. 339) argued would accompany the spread of a new model. I find that while voters penalized diverse union organizing before the crisis of the early 1980s, those penalties disappeared as more unions made reforms that supported new forms of organizing. That effect was not universal, though. Only the unions that had made such reforms saw smaller penalties from diverse organizing; other unions saw no change. These findings lend further quantitative support to theories of union revitalization. I conclude by discussing the implications of these findings for our thinking about how categorization systems like jurisdiction function in everyday life.

\section{Relational versus cognitive categorization}

Category systems have many of the characteristics that Durkheim attributed to social facts, those "manners of acting, thinking and feeling external to the individual, which are invested with a coercive power by which they exercise control over him" (Durkheim 1982, p. 51). A category scheme is useful to the extent that it is shared and thus can help different individuals with tasks like identification (Pólos, Hannan \& Carroll 2002), valuation (Zuckerman 1999, Zuckerman \& Rao 2004) and commensuration (Espeland \& Stevens 1998). Sociologists focus on those schemes that are agreed upon by different actors and used as aids in some kind of interaction, as when movie critics use genres to help explain films to potential audiences (Hsu 2006). Because such schemes' usefulness inheres in their being shared, any one actor has a limited ability to influence an act of categorization. This limited agency is what gives these systems their coercive power. Shared category schemes produce incentives for an actor to conform to one category and penalties for not conforming. Durable category schemes are those where most objects to which the scheme is applied fit well into one and only one of its 
categories (Zuckerman 2004, Hannan 2010).

By what mechanism is a social fact like a category system reproduced? Most recent categorization research draws upon laboratory work by cognitive psychologists, in which subjects were asked to classify various objects (Rosch 1973, Rosch \& Lloyd 1978). That research "reveals a strong tendency for persons to ignore all but the strongest membership when pressed to make inferences...about feature values" (Hannan, Pólos \& Carroll 2007, p. 101). In other words, when faced with an object, individuals refer to existing schemas in their heads and slot the object into the category where it seems most likely to fit. They ignore objects that do not have strong membership in one category or another (Zuckerman 1999), or judge them to be inferior members of whatever category they slot them into (Hsu, Hannan \& Koçak 2009). This research employs what I refer to as a cognitive mechanism for reproducing category schemes. Individuals evaluate objects based on explicit consideration of their fit to a preconceived and shared set of categories. When faced with a choice between a specialized and a diversified object, they prefer the specialist. In aggregate, their preferences penalize diversified objects, such that specialists are more likely to succeed or otherwise be legitimated.

In principle, cognition alone could sustain a categorization system. The cognitive mechanism sits uneasily with Durkheim's original conception of social facts, though. He argued that a social structure is rarely reproduced by people acting intentionally to reproduce it: "Not a single word of mine must be understood [to suggest] that social facts can be understood immediately by states of individual consciousness" (Durkheim 1982, p. 253). Rather, social structure was better characterized as emergent from lower-level interactions among individuals following often quite different motivations. Rather than asking why actors want to maintain a social structure, the sociologist should ask why the structure is maintained, given what the actors want. (Collins 1981) made a similar point when criticizing Parsonian sociology's focus on the reproduction of norms:

[S] uch "norms" are simply observer's constructs. It is a common, but erro- 
neous, slight-of-hand then to assume that the actors also know and orient their behavior to these "rules." The reason that normative sociologies have made so little progress...is that they assume that a description of a behavior is an explanation of it, whereas in fact the explanatory mechanism is still to be found. (p. 991)

Categorization theory faces the same empirical challenge as normative theory. The cognitive mechanism has rarely been demonstrated in the social settings on which much of the empirical work on categorization has focused. And there is always an issue of volition when applying results from laboratory experiments to social settings: the burden lies on the researcher to demonstrate that people embedded in a particular situation have reason to care about the same issues that a controlled experiment makes salient.

Martin (2009) develops a similar argument to Collins's regarding the orientation of actors to social structure. In his formulation, a social structure is only reproducible insofar as there is a duality between the observed structure and a "heuristic" that an individual member of that structure can follow. We rarely observe true pecking orders, for example, because to maintain a pecking order all its members have to monitor and adjust their relationships with all other members, based on those other people's relationships with one another. Individuals have no reason to change their deference to one another just to preserve the pecking order for its own sake, and so pecking orders quickly break down. In contrast, spanning-tree structures (such as family trees) can result from a very local heuristic, in which individuals defer to one another based only on how many generations separate their common ancestors, ignoring all of the other deference relations they or other people in the structure have. A similar example of such a heuristic, one that underlines how local interactions produce larger structures of relations, is the "hook-up" rule that Bearman, Moody \& Stovel (2004) describe in their analysis of sex networks in a high school. That network has a massive connected component that resembles a spanning tree, but they demonstrate that this large structure could be produced by teenagers who are simply trying to avoid sleeping with their ex-partner's new partner's exes. This behavior yields a spanning tree among agents who have no interest (probably a disinterest) in being connected in this way. 
Martin's heuristics and Bearman et al.'s hook-up rule are examples of what I refer to as relational mechanisms. What characterizes a relational mechanism is that the macro structure of interest emerges from the actors' behaviors without their having its construction or preservation as a goal. A cognitive mechanism requires individual judgment and decisionmaking with regard to the structure at hand, but a relational mechanism only requires the actors to engage in a pattern of interactions that produces the structure as a side effect, or epiphenomenon. White (2008) outlined such a process more than forty years ago when he described how culture would arise out of network interactions:

Some net[work]s persist for a very long time. The pair relation on which the net is based remains stable and clearly defined. New persons are added to and leave the net, but according to clear-cut rules. In such a net it is natural for the simplest kinds of indirect relations to be "institutionalized," that is, recognized in that culture as a distinctive new kind of relation. Indeed, the rules of admission to the net regulate an indirect relation. (White 2008, p. 11)

"The principal result of this evolution is the definition in the eyes of participants of a new type of relation" (White (2008, p. 6), quoted in Santoro (2008).) Following White's formulation, I argue that category schemes are as much a product of the patterns of interaction among people and organizations as they are of the organizational properties on which people discriminate.

What might a relational mechanism behind categorization look like? Zuckerman's (1999) early work on social categorization offers an example, albeit one that later research has largely ignored. Zuckerman focused on the "mediated" market for securities, wherein the buyers of firms' securities rarely studied the firms themselves but instead relied on analysts' reports. Securities analysts tend to focus their coverage of firms by industry. A firm that operates in several industries is less likely to be covered by any one analyst than a firm that operates in a single industry is. This means that buyers are less likely to purchase the "hybrid" firm's securities, as they see less coverage of them in the analysts' reports. As a result, hybrid firms' securities trade at an "illegitimacy discount."

Two mechanisms are at work in the securities-market story. The first-the analyst's 
decision to cover a firm - is cognitive. Analysts actively complain about not being able to figure out what a hybrid firm "really does," and make explicit decisions about whether to treat them as members of their industrial categories (Zuckerman 1999, p. 1421). Most subsequent categorization research builds off of this fact. But the second mechanism-the mediating role between buyers and sellers - is not cognitive. People are less likely to buy hybrid firms' securities, not because they themselves have made categorical comparisons, but because they have not been exposed to the hybrids. The interaction between firms and analysts and then between analysts and buyers reduces the chance that buyers would evaluate hybrid firms along any criterion, much less buy their products.

Category systems may involve cognition, but as social structures they also comprise interaction patterns that are stable over time. The categorization research that relies on mediated markets focuses on their usefulness as part of an identification strategy (in a mediated market, the researcher can better guess what information about candidates audiences might have), but the pattern of relations in a mediated market itself helps to reproduce the categorization scheme. For example, a firm's industrial specialization or lack thereof might matter considerably less if those who buy their securities did their own research, rather than rely on analysts.

Figure 1 makes this point visually. Organizations are connected to mediators, who are connected to actors (for simplicity, only one actor is shown). Organizations belong to category A, category B or both. The mediators form ties to organizations, following the cognitive mechanism. In this case, neither mediator forms a tie to organization 3, which is a hybrid. Actors form ties to mediators, and they do so indiscriminately. The result is that no path exists between the actors and organization 3-but this absence is not due to the cognitive mechanism. Rather, it is a side-effect of the relationship rule that actors only form ties to organizations through mediators.

[Figure 1 about here.]

The social structure depicted in figure 1 suggests an interesting situation. Suppose that 
organization 3 somehow contacts some actors directly, and those actors choose not to form a tie to the organization. It so happens that organization 3 is a hybrid; but has the actor rejected it because of its hybrid status, or because such a contact violates the traditional patterns of interaction? Both motives are possible but hard to distinguish without more information.

Considering the social structure and the resulting relational mechanisms that underlie many category systems has two advantages. First, it encourages us to think about how a social fact like a categorization system can persist without having to assume that individuals are always engaged in active cognition with regard to it. Given how many regularities of social life are typically unexamined (Jepperson 1991, Weick 1995, Clemens \& Cook 1999), this way of thinking helps us to fit many processes of categorization more easily into broader sociological theory about the maintenance of social structure. Second, relational mechanisms make it easier to see how category systems might break down. To see this, consider a world where cognition fully accounts for a categorization scheme. This means that everyone agrees on the relevant dimensions for categorizing the things to which the scheme applies. Such a system might break down if people were presented with a wealth of things that did not fit their established and agreed-upon categories; yet if a classification system is working and thus tending to penalize boundary-spanners, where would such anomalies come from? People might instead change the dimension upon which they choose to categorize things, perhaps through some change in their underlying theory of value; but this only begs the question of why a large number of people would suddenly change their minds. If, in order to explain why groups of people agree on such schemes or change their minds about them, we have to resort to exogenous shocks, then it is worth asking what benefit there is in focusing on cognition in the first place. Alternatively, if we posit that many categorization schemes are supported by stable interactions, then we only have to point to events that disrupt those interactions to understand why a scheme might be disrupted.

In the next section, I argue that this latter type of process characterizes what happened to 
jurisdiction in the American labor movement over the last generation. I focus in particular on how labor's "old" model of organizing relied on stable patterns of social interaction, wherein frustrated workers were typically referred by already-unionized workers to the unions' local business agents. With most workers tied to unions through business agents, the scope for employees to themselves evaluate different unions was sharply constrained. These patterns of interaction reinforced the system of union jurisdictions. The well-documented employer offensive against organized labor had the side effect of making this old organizing model untenable. Unions that have developed new organizing strategies have typically restructured the role and duties of their organizers, and developed a new pattern of interaction with workers. Today's more revitalized unions devote more effort to building trust and new ties to groups of workers, rather than relying on existing social connections. I propose that this new style of recruitment can help account for the weakening of jurisdiction.

\section{The decline and fall of industrial jurisdiction}

The AFL-CIO's historic principle of exclusive jurisdiction resembles the categorical systems that recent work has studied. Organizing activity, mergers and voter behavior largely conformed to those jurisdictions in the 1960s and 1970s. Beginning in the 1980s, though, that conformity broke down. Unions increasingly tried to enroll workers across more industries, mergers united unions in less-and-less related industries and voters became more likely to vote for unions that organized across industries. Yet despite environmental changes that would encourage all unions to diversify their membership, unions' attempts and success at doing so have been uneven.

Jurisdiction, in and of itself, has received little scholarly attention in recent years. Industrialrelations research into changes in unions' jurisdictions (Chaison \& Dhavale 1990a, Chaison \& Dhavale 1990b, Dunlop 1988) describes the rise of "conglomerate unions" but offers little theory to explain the phenomenon or to predict why some unions would be more inclined to 
build conglomerate memberships than others. Work on labor-union revitalization meanwhile has paid close attention to the distinct tactics that "revitalized" unions use in their campaigns (Bronfenbrenner \& Hickey 2004). Many of the unions that employ such tactics are the same unions that have been called conglomerates, but neither stream of research has considered the interaction of new union organizing tactics with the older jurisdictional system. This section describes the relevant details of the AFL-CIO's jurisdiction system and the relevant changes that the system underwent after labor's "time of troubles" (Lichtenstein 2002, p. 212) in the late 1970 s and early 1980s.

\subsection{Before 1980: Decentralized, tactical organizing}

Organizing since the 1950s has officially taken place under the AFL-CIO's principle of exclusive jurisdiction. The use of the term "raids" to describe organizing attempts within another union's jurisdiction reflects the normative value placed on this division of labor. Thus for example the original constitution of the American Federation of Labor, adopted in 1882, reads that

No charter shall be granted by the [AFL] to any National, International, Trade, or Federal Labor Union without a positive and clear definition of the trade jurisdiction claimed by the applicant, and the charter shall not be granted if the jurisdiction claimed is a trespass on the jurisdiction of existing affiliated unions, without the written consent of such unions... (Article IX, §II; emphasis added)

Unions frequently affiliate to confederations that have formal no-raiding agreements (Ulman 1955). Most of the unions studied here are or have been members of the AFL-CIO, which was formed in 1955 in large part to end jurisdictional battles. Union organizing largely conformed to those the AFL-CIO categories. This pattern of organizing began to break down after about 1980, during "the last gasp of the postwar capitalist labor accord in the U.S." (Wallace 1989, p. 11). The exact start date of the trade-union collapse has long been debated (Farber \& Western 2002, Lichtenstein 2002, Fantasia \& Voss 2004, Tope \& Jacobs 2009). Because this study focuses on changes to organizing, a useful break point 
is the collapse in union organizing during the deep 1982 recession, shown in figure 2 and described in Tope \& Jacobs (2009). Having averaged about 7,000 drives per year for nearly two decades, organizing fell by more than half in 1982. Activity rebounded the following year but only to about half the old level. Part of this decline represented increased selection by union organizers - as the win rate in figure 2 shows, the share of successful drives rose in this period-but, since unions had long struggled just to organize enough new members to offset attrition, the lower post-1982 organizing rates began a sharp and sustained decline in union density.

[Figure 2 about here.]

Unions' organizing grew more diverse across industries after 1982. I measure the diversification of unions' organizing across industries using a Hirschmann-Herfindahl index where the shares are the portions of a union's organizing activity in each three-digit SIC industry. The index is weighted to account for how related different three-digit industries are. ${ }^{1}$ On this measure, a value of one indicates complete concentration of a union's organizing activity in a single three-digit industry. Organizing in more industries or spreading one's organizing more evenly across industries will lower the score. Figure 3 plots this measure of diversity over time for the AFL-CIO as a whole and for selected unions. Before 1982 industrial concentration among AFL-CIO unions' organizing was relatively high; the ILWU, which was outside the federation until 1988, is plotted for contrast. Concentration within the federation was also comparable for different unions. ${ }^{2}$ After 1982 the average concentration of organizing by AFL-CIO unions increased; no comparable change occurred in unaffiliated organizing. Furthermore the AFL-CIO unions' activities resemble each other less after 1982. I plot three member unions in figure 3 for illustration. The Painters (PAT) changed their practices very little; the Carpenters (UBC) diversified their organizing roughly in line with the federation as a whole; and the Autoworkers (UAW) diversified such that by the late 1990s they more

\footnotetext{
${ }^{1}$ Calculation of these weights and the index is described in the data and variables section below.

${ }^{2}$ The AFL-CIO includes craft unions that organize across industries. Thus the AFL-CIO average slightly understates the industrial unions' concentration.
} 
resembled the once-unaffiliated ILWU.

[Figure 3 about here.]

In the past, diversifying its organizing across industries would have lowered a union's win rates. Figure 4 however reports the estimated coefficient, from a probit model on all organizing drives between 1961 and 1999, of a union's organizing diversity on the likelihood that the union would win a representation election. The penalty that was present in the 1960s and 1970s disappears in the 1980s. Thus several of the features that made the labor movement resemble a categorization scheme collapsed a generation ago, during the same period when labor activists and scholars were beginning to talk about the need to fundamentally rethink many unions' strategies. It is that collapse and its implications that I explore below.

[Figure 4 about here.]

From the 1950s into the 1980s, most union-organizing activity was decentralized. National unions devoted minimal staff and resources to recruiting new members. Instead, the union locals usually undertook the task, largely through their business agents. The role of business agent has no exact analog outside of the union movement, but it has several noteworthy structural parallels with the securities analysts, film critics and other "mediators" described above. In most union locals, the business agent is not a rank-and-file employee but rather a full-time union staffer who is paid through the members' dues. The agent's duties can include hiring staff, keeping records, collecting dues, handling grievances and (virtually always) participating in contract negotiations with the employer. The agent was also often the main representative of the larger union to the members of the local: "The...staff is "the union,' in their own minds and in the minds of workers." (Clawson, p. 10) It is a classic broker's role. As an organizer and representative of the union, the agent was expected to monitor other firms and workplaces in their bailiwick and make the case to potential members for affiliating with their union. $\mathrm{Karl},{ }^{3}$ a former clerical worker and now union staff

\footnotetext{
${ }^{3}$ Exclusive jurisdiction makes protecting respondent anonymity difficult. I have avoided naming unions wherever possible and tried to substitute comparable unions (other building trades, other service unions)
} 
member, described the pattern:

The classic term is "hot shops." Hot shops were places that weren't unionized, maybe because they were small, maybe the union had lost a drive there in the past, or they were new. The locals would know about many of these shops, and they would keep an eye out for when the employees were pissed off or when the union had bargained a good deal [elsewhere], and they'd swing through then.

Such organizing was tactical rather than strategic (Kochan, Katz \& McKersie 1986, Perry 1987, Fiorito, Jarley \& Delaney 1995, Delaney, Jarley \& Fiorito 1996). Business agents usually came from the ranks of industry:

Karl: When I began [in the late 1970s], the typical organizer was still someone from the industry who had taken part in an organizing drive... who had sometimes won, but often who had lost and then been "let go" for his union activity. The local would keep that person around, planning to try again at his shop in a year's time... they might have a drive going on across town in the meantime, and they'd have him go work on that. You do a few of those, and soon you're an organizer.

Mike, retired business agent: I started organizing when business was slack. I had seniority and I had a loud mouth. The [regional] office knew that I'd worked all over the place, so when they went after a company they liked to send somebody like me, who might know people.

This homophily, in which local organizers focus their efforts on the economic and typically social milieu from which they themselves were drawn, has strengths and weaknesses. On the one hand it can be seen as the residue of an older, more community-based labor movement, where leveraging social ties was a critical element of organizing success (Lichtenstein 2002). On the other hand, it reproduces social segregation (Katznelson 1981, Cumbler 1989, Frymer 2003). Researchers have frequently criticized how these campaigns did not involve much participation by or empowerment of the workforce itself (Clawson 2003, Fantasia \& Voss 2004). Yet in an institutional environment that was more friendly to labor organizing, such tactics were reasonably effective at enrolling new members.

whenever feasible in quotations. Respondents' names are also changed. 
My goal in describing these older tactics is not to defend them; obviously they were ineffective at responding to increased employer opposition to unionization after the 1970s. My goal instead is to highlight the way that this pattern of interaction - workers who were connected to unions in their industries via business agents-helped reproduce the unions' jurisdictional system. Because groups of workers were referred to or contacted by business agents, they had little opportunity or incentive to compare different unions that might represent them:

Frank, building trades organizer: I have not met the electrician who would not join the Carpenters because [they] had 'Carpenters' in the name.... [I]t was more that, in the old days, you wouldn't see a carpenter. If you were an electrician, and you were thinking about joining. . . there was a union for you to join: the Electrical Workers. [Interviewer: Didn't the Electrical Workers organize in places like GE factories, though?] Sure they did, but that was the exception that proved the rule... most of the time, when you went looking for a union, you already knew which one you were looking for.

Workers "knew" which union they were looking for because they already had social contacts among unionized workers who could point them in the right direction. Joseph, an organizer active from the mid- to late 1960s, insisted that "We didn't really pick that often":

You wanted a union? Fine, you probably had an uncle in the trade, or a brother, and he'd put you in contact with somebody. [Interviewer: Was it usually family?] No, not always, but you knew somebody you trusted. And that was your union.

Joseph's comment underscores that workers were not dependent on being contacted by a business agent, insofar as their other social relations would funnel them toward the right party. That advice was not based entirely on immediate social contact, but still it encouraged workers to go through traditional channels:

Interviewer: What if you worked in an auto-parts plant, and your uncle worked in a furniture plant? Would you join the Furniture Workers?

Paul, former utility worker: Sometimes. I think some unions used to get members that way. But it wasn't the norm. I think, back then, it was more likely he'd tell you to get in touch with the Auto Workers, or maybe the Machinists, because they'd be the ones that could get you a good contract. 
The point is easy to overstate. Paul's comment, that workers workers knew which union could probably get them a good contract, reflects that jurisdiction did not arise out of thin air. The AFL-CIO's industrial jurisdiction scheme had explicit an justification: high density within an industry was a prerequisite for building countervailing power against employers, because more-replaceable unskilled workers would benefit from less-replaceable skilled workers' refusal to work. Disputes as for example between craft and industrial jurisdictions (See Dunlop (1958) for an overview) were disputes over whether industry was the best dimension on which to specialize to bargain better contracts, not over the goal itself. But that union officials argued over these points does not mean that, in the midst of a specific organizing drive, workers systematically evaluated different unions on these criteria. Many such arguments - which, being arguments about how to categorize groups of jobs and workers, resemble cognitive categorization - had been hashed out in the past, during the foundational disputes between the original AFL and CIO. By the "mature" labor-relations era of the 1960s and 1970s, those justifications were largely unexamined, and subsumed within the day-to-day pattern of social relations.

Sal, retired Masons business agent: What you know [as a business agent] is that if a guy from the Carpenters or [Teamsters] or whoever shows up at a job [site] and starts talking, they're going to be like, "Who the hell are you? We don't know you. We don't trust you. Why would you come singing to us all of a sudden?" They know it's weird, this guy just comes by.

Maria, clerical worker and union steward: They came from industry, the [union] did, and I remember that was for us so bizarre... [Interviewer: Because they wouldn't know how to represent you, to bargain for you, that it was bizarre?] No. If I thought about it, maybe....But that wasn't how we talked about it. You know, they had other secretaries and type in the union already, we knew that. There was this sense that they were from another world still.

Mike: Raids make you suspicious. Someone raiding you. This is just a jerk off the street, to you.

"The burden of proof was on someone from the outside," was how Joseph summarized the situation. Comments like these do not mean that workers in the past were excep- 
tionally insular, or that organizers were exceptionally bad at bridging the social distance existed between a union and its potential members. Building initial trust with potential members is one of the main issues that union-revitalization efforts today wrestle with (Bronfenbrenner 1997, Cohen \& Hurd 1998, Rooks 2004). When union density was higher and worker-union contacts were more frequent, though, the relative appeal of new, different representatives was even less - and the unfamiliar interactions, the connections across normally separated social groups, rankled at least as much as a given union's fit to a jurisdictional category. Cognitive categorization presumes actors explicitly weighing alternatives and making decisions; yet much social interaction is neither conscious nor explicit (Berger \& Luckmann 1966, White 2002), based instead on enacting scripts and evoking justifications only in retrospect (Weick 1979, Weick 1993). Interaction routines such as the shunting of potential union members to specific unions because of pre-existing social ties remind us that we need not place tremendous cognitive weight on the operation of stable categorization schemes. Routines based upon them can operate with quite little conscious thought devoted to the basis for the routines. For example, the decentralized structure of union organizing was a key mechanism for reproducing the jurisdictional system, one that required virtually no explicit consideration of category membership by potential union voters.

Decentralized organizing was not universal. The Steelworkers for example tended to do much of their organizing work through their national headquarters in Pittsburgh (StepanNorris \& Zeitlin 2003). At least within a union's core jurisdiction, such centralized organizing practices worked well, as evidenced for example by the Steelworkers' density in Pennsylvania and Ohio. When such unions tried to organize in new industries or geographic areas, as for example when the electrical unions followed firms like GE into the south (Schatz 1983), their campaigns often required separate, paid organizers who had few social connections to the community and who had to win over workers despite little personal or social history in the industry. Such centralized and long-range efforts were the exception in the two decades after 1960. These organizers gained none of the leverage of repeated interaction and also 
faced the hurdle of building trust with potential members to whom they had to make a case for why theirs rather than the dominant union in their industry would be able to win the best agreement with employers (Ganz 2000).

\subsection{After 1980: Centralized, strategic organizing}

Union organizing since 1980 has happened in the teeth of declining membership, from nearly one third of private-sector workers in 1960 to 9 percent in 2000 (Hirsch \& Macpherson 2004). Peter, a former staff analyst of a large international, described the change:

It used to be that union members were around. If you weren't one, you knew one. You didn't shop for unions, you looked one up. That wasn't true everywhere - in the south, of course, there weren't unions. There, unions had to introduce themselves, through the organizers, who weren't locals usually. It's like everywhere's the south today.

Today I think it's a lot easier to find out about a lot of unions. You can go online. But the personal connection, through your community, that kind of trust... that's gone.

The collapse in industrial density undermined the unions' bargaining power with employers. The union wage gap for example has consistently declined since the late 1970s (Freeman 1985, Wunnava 2004, Eren 2007). Falling membership reduced density, which weakened the union's appeal, which further reduced membership. This has undermined the primary strategic justification for specialization by industry.

Had the recession's effects been merely economic, the recovery that began in 1983 should have pushed the jurisdictional system back toward its old strength. Yet most industrial relations observers agree that the early-1980s recession marked a break with previous downturns (Isaac, McDonald \& Lukasik 2006). Neither organizing activity nor total membership rebounded during the recovery as they had in the past (Kochan, Katz \& McKersie 1986). Explanations for this continued stagnation vary, but most scholars agree that increased employer opposition to unionization, seen for example in the explosion of unfair labor practice (ULP) charges filed against employers during organizing drives (Flanagan 1989, Bronfen- 
brenner \& Juravich 1995), played a major role (Roomkin \& Block 1981, Block \& Wolkinson 1986, Kleiner 1984, Freeman \& Kleiner 1990).

It is upon this era, in which traditional union organizing tactics have been hobbled, that most union revitalizaton research has focused. As that work has documented, when faced with entrenched employer opposition, several unions acknowledged that their decentralized business-agent organizers could no longer win campaigns (Voss \& Sherman 2000). The organizers interviewed agreed that the world of going after "hot shops" had passed. Peter noted the contrast; building on his comment that "It's like everywhere's the south today," he said that "Today's organizing drives resemble the ones the unions tried in the South in the 1940s, like Operation Dixie," the CIO's massive (and massively unsuccessful) campaign to organize southern textile and forestry workers after World War II (Griffith 1988). The role of organizers is quite different in such a campaign. The union has multiple targets - an entire firm, an industry within a city - rather than a single one. This change in focus came from changes in employer resistance:

Karl: [When] employers largely accepted unionism... you could focus on how much the employees wanted to unionize. But today the employers resist so fiercely and the government largely stands aside, so the employee is less important in a way - it doesn't matter how much they want the union, if the employer is deadset against it, you'll lose. So you have to organize the employers, in a sense. And that means more [staff], bigger drives.

Thus both who becomes an organizer and what an organizer does has changed. "More staff" often means teams of organizers, frequently operating out of the national headquarters and visiting different cities during campaigns. The members of those teams may themselves have little personal experience working in the industry that the union tries to organize. As with so many other jobs in the not-for-profit sector, over the last generation union organizing has become increasingly professionalized (Markowitz \& Tice 2002, Osterman 2002, Huising 2008). Karl contrasted the organizer who came out of the workplace, often in the context of a failed organizing drive, mentioned above, with his modern counterpart: 
Today there's so much more work picking industries, targeting industries, developing corporate campaigns.... You need more experience with the employers as a group and the industry, so a lot of people on these teams aren't from one jobthey're analysts. You still need people who can win the employees' trust, that's paramount, but they aren't using their personal history to do that as much.

To compensate for this change, many unions have recruited and trained organizers who are skilled at rapidly involving members of the proposed unit in the drive, empowering workers to make the case to one another why they should vote for representation (Sharpe 2004).

Emma, healthcare organizer: I've never been a nurse. My job isn't to walk in like Super Nurse. My job is to find Super Nurse, who usually doesn't know she's Super Nurse. I need [other nurses] to trust me... the best way is for someone they trust to trust me. They'll believe her when they won't believe me...

Trade unionists in recent decades have not had the luxury of established relations that they can leverage. In almost all of Clawson's (2003) studies of innovative organizing campaigns, for example, the union in question had to build ties to groups of workers who not only were skeptical that they could win an organizing campaign but did not take it for granted that union representation was best or even right for them. Indeed, as Lopez (2004) points out, part of the modern organizer's job involves explicitly countering the image of business unionism that shapes many workers' antipathy to unionization. Countering this means not relying on traditional channels for support and legitimacy.

The diffusion of such practices among unions and union organizers is by no means complete. Where such practices have diffused, though, the relationship between unions, organizers and workers has been profoundly transformed. First, such organizers coming "from the outside" are better at building ties to workers than they often were in the past. Second, the once-dominant way of getting put in touch with a union - contacts through existing social ties - is often absent, because union density has declined so sharply. Third, even if a union that was specialized in the workers' industry could in principle negotiate a better contract, that union may not have developed the capacity win new, more strategic orga- 
nizing campaigns. Workers must consider the benefits of joining a given union conditional on that union's being able to organize them. Unions who cannot win organizing drives are devalued; unions that have little industry experience but a record of organizing success are valued. Carlos, a former service-sector employee who later joined his union's office of corporate campagins, emphasized the role that such a track-record plays:

It isn't useful to go over the things you can get them in the negotiations. At least not at first... you have to show them that you can get into those negotiations at all. And that means you talk up how you've unionized other groups of employees. [Interviewer: Similar employees, normally?] It helps, but they don't have to be. When you're selling yourself as an organizer, it's almost more impressive to say that you've brought in all kinds of different workers, because it shows that you can handle a lot of different challenges.

In short, an unintended side effect of many union-revitalization efforts has been the creation of oganizing units that are better at making connections to new groups of workers. Those workers, in turn, have been receptive to such unions' appeals, relative to how they were in the past. Many case studies of union revitalization have made this point (Clawson 2003, Voss \& Sherman 2000, Bronfenbrenner \& Hickey 2004); I propose that, if the point holds, then when we analyze the bulk of organizing drives over the years, we should see a relationship between union reforms that have supported such organizing, and the decline of jurisdiction as a force shaping voter behavior.

\section{Actions to be explained and hypotheses}

Before turning to the quantitative analysis, it is worth laying out several of the points made above as formal hypotheses. The data I analyze are the records of union-representation elections. Union election data are useful empirically for investigating how audiences evaluate specialized and diversified organizations, for two reasons. First, votes are a direct measure of support or rejection of an organizational candidate. By comparison, much work on categorization has had to rely on more indirect measures of organizational support, such as sales 
or survival (though see Kovacs \& Hannan (2010) and Kovacs \& Hannan (2011) on reviews and ratings). Second, election records are opened before the election takes place, ${ }^{4}$ which means that failed organizing attempts are recorded in the literature. This makes it possible to distinguish between organizations that tried and failed to diversify, and organizations that never tried.

Hypothesis 1 A union is more likely to win an organizing drive if that drive takes place in the union's core jurisdictional industry.

Hypotheses 1 underlies the other hypotheses formulated here. In order to talk about the weakening of jurisdiction in the context of representation elections, it must be the case that there is some base effect on election outcomes when a union organizes outside of its own jurisdiction. I discuss how I operationalize a union's core industry or industries below.

Hypothesis 2 Greater industrial diversity in union organizing is associated with lower probabilities of winning in organizing drives.

Where hypothesis 1 focuses on the context of a specific organizing drive, hypothesis 2 considers the impact of violating jurisdiction on a union's overall reception by workers. This hypothesis derives both from categorization theory's assumption that "[G]eneralists - those with membership spread over categories - are likely to be judged as having inferior offerings in markets in which specialists can be found in all categories" (Hannan, Pólos \& Carroll 2007, p. 109) and from union-specific work on how diverse memberships should weaken union appeal to any one group of workers: "Although such diversification strategies may hedge against uncertainty by reducing the union's dependence on a single exchange relationship... diversification requires a union to adapt to unfamiliar environments and workers

\footnotetext{
${ }^{4}$ Unions can file such petitions with the NLRB once they have signed cards from at least 30 percent of the proposed bargaining unit, expressing interest in holding an election. This is a non-trivial hurdle. Much employer opposition, including much illegal opposition such as intimidation and firing, takes place during the card drive. Also, any union that files an election petition has self-evidently established some ties with the potential new members. Thus any voter penalties suffered by unions in elections should be thought of as conservative evidence of the phenomena described here, for they are penalties applied to unions that nonetheless had enough support to try an election. Card-drive data would offer a cleaner test, but no representative, longitudinal data on card drives exist.
} 
who differ from traditional members" (Fiorito, Jarley \& Delaney 1995, p. 619). Not only would workers outside the union's historic jurisdiction need convincing that the union cared about and could represent their interests but the union could also alienate their present and future audiences by "diluting the union's community of interest and obscuring its identity, thereby adversely affecting members' solidarity and commitment" (Cornfield 1987, p.190).

Hypothesis 3 Centralized organizing practices are associated with a higher probability of a union's winning an organizing drive.

Hypothesis 4 Centralized organizing practices do not offset the penalties of organizing outside one's jurisdiction.

Hypotheses 3 and 4 are based on the historical circumstances around centralized organizing departments, as discussed above. Some unions, like the Steelworkers, maintained centralized organizing departments and for many years had good results with this approach. However, those unions mostly focused on organizing within their own jurisdictions. At least before the 1980s, such departments were not associated with success at breaking into new industries and enrolling new groups of workers. On this point, Ganz (2000) seminal study of the United Farm Workers in California offers a valuable example. The IBT mounted a large and centralized campaign that aimed to organize many of the workers who ultimately formed the UFW. That campaign failed; the efforts by César Chávez and the organization he built, which relied on deep local connections to the Chicano community in California, prevailed. This pattern also appears in Schatz's (1983) study of the postwar electrical workers and Griffith's (1988) history of southern textile workers.

Hypothesis 5 The negative effect of diverse organizing should grow smaller when more unions have adopted centralized organizing practices.

Hypothesis 6 Any reduction in the penalties associated with diverse organizing should only accrue to those unions that have themselves adopted centralized organizing practices.

Hypothesis 5 is based on the idea, mentioned by informants and supported in the unionrevitalization literature, that centralized, professionalized organizing departments have since 
the mid-1980s been part of a larger package of organizational reforms aimed at adapting to a more hostile environment. In particular, these are the departments described by many researchers of the "new union movement" (Bronfenbrenner 1998, Milkman \& Voss 2004). Based on the discussion above, I hypothesize that the spread of such reforms reflects the shift in interaction patterns that have eroded any relative advantage that traditional organizing practices gained from being able to leverage pre-existing social ties.

However, hypothesis 5 by itself is an insufficient test of the effect new organizing techniques have had on how workers perceive jurisdiction. It is conceivable, for example, that jurisdiction might have simply collapsed in the early 1980s. If union strength declined in most industries, then workers might simply have abandoned the cognitive schema of industrial jurisdictions, because jurisdiction offered little of value. This would imply that all unions would see weakened effects of jurisdiction as more unions adopted structural reforms. Yet most work on the contemporary labor movement agrees that unions vary widely in their embrace or rejection of strategic reforms. If jurisdiction tended to be reproduced by lowerlevel, relational mechanisms like the pattern of interaction between workers, business agents and unions, then the declining effects of jurisdiction should be most apparent where those patterns have changed the most - that is, among those unions that have made reforms. Thus hypothesis 6 implies that such benefits should be localized to reformed unions.

\section{$5 \quad$ Data and variables}

The hypotheses of this study are operationalized using three variables - the diversification of a union's organizing across industries, having a centralized organizing department ${ }^{5}$ and the number of unions that have adopted such departments - and their interactions. Industrial jurisdiction implies penalties for unions that organize outside their jurisdiction, so the diversity of each union's organizing drives across industries each year is used to verify this.

\footnotetext{
${ }^{5}$ Data were also gathered on unions' adoption of professionalized organizing staff. Models using this measure and the number of unions professionalized yield very similar results to the models using centralization, and are available from the author upon request.
} 
Structural reforms to how unions conduct their organizing are theorized to offset such penalties. The centralization of organizing at the level of the national union is tested here as an example of such a reform (Martin 2007). As interview respondents repeatedly stressed, unions began creating such departments in the 1980s to overcome what they saw as fierce employer resistance to organizing campaigns. Unions that created such departments were also likely to change their organizing staff and the structure of their campaigns, to bring in precisely the type of organizer who could not necessarily stress his or her union's deep experience negotiating contracts in the potential members' industry but who could both point to concrete actions that her union had taken to try to overcome or neutralize such employer resistance and build trust among new groups of workers. Per Carlos's comment above, it is such unions that can "sell themselves" as organizers to workers in unfamiliar industries. Thus having such a department is hypothesized to make election victory more likely. Such centralization is a crude measure of this change, since of course a union could create a national organizing department staffed with veteran organizers. Such an organizational structure is a necessary condition for potential members to perceive a difference in how such a union might differently serve their interests, though, so its presence within a union is a useful proxy.

The number of unions that have adopted centralized organizing departments is used to operationalize the shift in "cultural expectations" that (Voss \& Sherman 2000) proposed must accompany individual union's reforms if new organizing strategies were going to have significant effects. As figure 5 shows, increases in these adoptions do correspond closely to increases in the share of currently-unionized employees represented by such unions. A nice feature of this measure is that it does not spike in 1982, when organizing first collapsed, which would be inconsistent with the widespread acknowledgement that unions were slow to respond to their changed environment with changed routines (Craft 1991). Instead, the practice only really starts to spread in the late 1980s and early 1990s. This lag in the adoption of such practices is helpful for testing the alternative hypothesis that the penalties associated with diversification simply collapsed during the early-1980s recession. 
[Figure 5 about here.]

The main effect of number centralized should be positive because it corresponds to the spread of a new theory of value. Figure 2 showed that win rates have risen over time, though, and the number centralized itself varies in time, so no theoretical conclusions can be drawn from a positive effect in and of itself. Instead, the interactions of these three variables will be important to test. Interacting diversity with centralization for example tests whether audiences penalize unions with this new feature less than they do other unions when the union tries to span jurisdictions. Interacting centralization with the number of unions that have adopted centralization checks whether the benefits of centralized organizing have always existed and were belatedly realized by many unions, or whether such benefits only appeared as more unions made the change. Interacting diversity with the number centralized meanwhile tests whether the penalty associated with violating jurisdiction declined.

These two-way interactions should do not by themselves capture the full story, though. Diverse organizing through a centralized department for example should not make success more likely if it takes place early in the study period, when voters could rely on local contacts to business agents. Indeed such tactics may be a net hindrance early on; thus the expected sign on the two-way interaction is ambiguous. Similarly, diverse organizing by itself should not produce benefits, even if many unions have restructured their organizing. If potential members reward new organizing strategies and not diversification for its own sake, then they will only be more likely to vote for a diversely organizing union if it is one that has also

embraced such reforms. A three-way interaction between diversity, centralization and the number of unions that have centralized is therefore included to test for the effect of all three elements' being present, per hypothesis 6 .

\subsection{Data sources}

In union organizing drives the measure of support is a vote for or against a candidate union in a representation election. Under the National Labor Relations Act (NLRA), the basic 
law covering trade-union formation in the United States, a union can petition the NLRB to hold a secret-ballot election at a workplace in order to determine the employees' interest in having the union represent it in collective bargaining with their employer over the terms and conditions of employment. The union must present signed cards showing interest by at least 30 percent of the employees in the proposed bargaining unit in holding an election. Conditional on clearing several procedural hurdles, the NLRB schedules and conducts the election on average within two months of the petition's filing. A simple majority of votes cast is required for victory, upon which the NLRB certifies the union as the employees' representative. The employer is then legally obligated to bargain "in good faith" with the union for one year before any further actions can be taken (McGuiness \& Norris (1986) have a detailed review of the process). The efficiency and effectiveness of this process has been a subject of heated debate for many years, ${ }^{6}$ but despite its flaws the election procedure remains virtually the only way that unions can enroll new members without the cooperation or neutrality of the employer, which is rare.

The primary data used to test these hypotheses come from the FAST database of NLRB election petitions, originally developed by the AFL-CIO's Food and Allied Service Trades Department and now maintained by the Federation's Collective Bargaining Department. The FAST data is nearly complete; the cases that do contain missing variables, such as industry, appear to do so at random. The NLRB and other policymakers have treated these data as representative of labor organizing in America for decades (cf. NLRB (2007)).

The FAST database holds 213,861 records. I exclude three groups of records for theoretical and empirical reasons. First, most craft unions are excluded. There is little theoretical

\footnotetext{
${ }^{6}$ Particularly over the last decade, many unions have given up on being able to organize large numbers of workers through the NLRB election procedure and have focused directly on corporate campaigns to secure voluntary recognition by the employer (Brudney 2005). Such a strategic shift is a logical extension of the reforms discussed here. Such units will only show up in the NLRB data when the parties formalize their voluntary agreement by requesting an election. Since many of these newer campaigns involve unions outside their core industries, ignoring them probably understates the impact of centralized organizing on success when operating across industries. This shift to voluntary recognition is a relatively new phenomenon, growing more important in the late 1990s. Since these data end in 1999, the effect of voluntary campaigns should be small here.
} 
reason to assume that craft unions would face the same penalties for violating industrial jurisdictions that industrial unions do, because craft unions do not have industrial jurisdictions. The craft unions' actual jurisdictions, based around occupations, are not recorded in the FAST data, which makes it impossible to calculate any meaningful measures of their organizing diversity. The exception to this are the "compound-craft" unions such as the Carpenters (Ulman 1955) that historically expanded their organizing to cover multiple crafts in a single industry (usually the building trades) and thus by 1960 resemble industrial unions more than craft unions (Hannan \& Freeman 1988). Excluding the compound-craft unions does not change the substantive results. Craft unions account for 44,849 records.

Second, unions that are independent from the AFL-CIO for the entire time period are excluded. Such unions are not subject to the federation's no-raiding agreements and there is no theoretical reason to assume that they should be bound by the same jurisdictional principles as member unions. Excluding independent unions also removes the International Brotherhood of Teamsters (IBT) from the analysis. There is a stronger reason to exclude the Teamsters, though. The Teamsters were expelled from the AFL-CIO in 1957 for racketeering and remained unaffiliated until late 1995. Throughout the period the Teamsters launched more organizing drives, more diversely, than any union, and they also lost more drives than anyone. The Teamster's win rate only began to improve in the late 1980s after a long and difficult change in leadership. Because the Teamsters launched so many organizing drives that only began reliably to succeed late in the time period, including them in the analysis would produce results that appear to support my hypotheses despite the obvious alternative explanations for the Teamsters' trajectory. Unions that disaffiliated for part of the period are included in the models; an indicator variable tracks their affiliation. Independent unions account for 69,312 records.

Third, because this analysis considers the impact of industrial diversity of a union's organizing on its success, including unions that have very few drives and thus by definition very little diversity can overstate any effect of diversification. I therefore exclude those unions 
that averaged fewer than ten organizing drives annually in the study period. Such unions account for only 3,400 records. The resulting dataset holds 86,299 records for 92 industrial and compound-craft unions that were affiliated with the AFL-CIO for all or part of the study period. These records comprise 43 percent of all election petitions filed.

The FAST Department supplemented the NLRB's records, adding for example the establishment's industry in the form of the three-digit SIC code, in which the potential bargaining unit was employed. As discussed below, I use these data to construct measures of industrial diversification for unions' organizing efforts over time. For that measure, I also draw on the Standard 85 Poor's Compustat Industry Segment files. Data on union density come from the Union Membership and Coverage Database from the CPS (Hirsch \& Macpherson 2004). Data on employment, including unemployment, come from the Bureau of Labor Statistics, including the Current Employment Statistics and Local Area Unemployment Statistics data series.

\subsection{Primary variables: Diversification and centralization}

The diversification of a union's organizing efforts is measured here using a HirschmannHerfindahl index that has been weighted by the relatedness of its component industries. An unweighted index of diversity would simply be the sum of squared shares of organizing drives across all three-digit SIC industries. Such an index has a serious bias. The SIC makes fine-grained distinctions between different types of production industries but coarse-grained distinctions between different types of service industries. Because most American unions have their roots in manufacturing, an unweighted index based on the SIC will overstate diversification within manufacturing while understating diversification outside of manufacturing and thus understate differences in unions' diversification. One corrective is to adapt the procedure outlined in Teece, Rumelt, Dosi \& Winter (1994) to generate a matrix of weights, $\tilde{\mathbf{T}}$, based on how related industries are. ${ }^{7}$ If $\delta$ is a $k \times 1$ vector containing the shares

\footnotetext{
${ }^{7}$ This procedure builds off the assumption that the frequency of firms' operation in multiple industries is in part a function of how closely related those industries are. That procedure yields a matrix $\mathbf{T}$ where
} 
of a union's organizing drives in each of $k$ industries in a given year, then diversification is calculated as $\delta^{\prime} \tilde{\mathbf{T}} \delta$. It is this measure that is plotted in figure 3. In the models, I subtract the index from one so that the coefficients have the intuitive interpretation of increasing diversity.

This index resembles the share of a union's membership in the industry of its greatest concentration as operationalized by Maranto \& Fiorito (1987). That study was the first to hypothesize that "the extent of membership concentration in one industry is expected to have a differential effect on a union's organizing success, depending on whether the election unit is in its primary jurisdiction" (229). The weighted index extends this reasoning in two ways. First, Maranto and Fiorito were more concerned with how overall diversification would affect the advantage a union had in organizing within its "primary jurisdiction" rather than its likelihood of success outside that jurisdiction. Second, the arbitrary designation of a "primary" industry makes less sense when for example only 11 percent of a union's activity takes place within that industry in a given year. Focusing on a single two-digit SIC industry also ignores that many unions' core memberships were and always have been spread across two or more two-digit industries. A Herfindahl index better reflects genuine diversification by capturing both the weight of any dominant category and the distribution among lesser categories. I also include the square of diversity in the results presented here, to account for the possibility that the level of diversity partly reflects past organizing success. ${ }^{8}$

Data on the centralization of organizing was gathered in telephone interviews with staff in the unions' organizing departments or (where no central organizing structure existed) the equivalent to the operations department in the national union's headquarters. Respondents

$\left(\left(t_{m n}\right)\right)$ is a t-statistic measuring deviation of the observed frequency of firms operating in industries $m$ and $n$ from the expected frequency based on the marginal probabilities of firms' operating in $m$ and $n$, where the probabilities follow a hypergeometric distribution. To use these t-statistics as weights, I calculate the matrix $\tilde{\mathbf{T}}$, where

$$
\left(\left(\tilde{t}_{m n}\right)\right)=\begin{array}{cll}
\frac{t_{m n}}{1.96} & \text { if } \quad t_{m n}>1.96 \\
0 & \text { if } \quad-1.96 \leq t_{m n} \leq 1.96 \\
\frac{-1.96}{t_{m n}} & \text { if } \quad t_{m n}<-1.96 \\
1 & \text { if } m=n
\end{array}
$$

${ }^{8}$ Excluding the square does not change the direction or significance of the main effect of diversity. Models including unions' lagged win rates, discussed below, show similar results. 
were asked, "Does your union have a national-level office in charge of organizing? [If yes] When was it established?" The answers were then used to code a dichotomous variable for centralized organizing. In the same interview respondents were asked, "What type of background do you look for in an entry-level organizer? What skills are important for an organizer to do their job? What background do your senior organizers have?" Unions where respondents noted that new organizers were expected to have college degrees or similar experience, a background doing online or other research, or quantitative skills were coded as having an emphasis on a professional organizing staff. In principle such a staff can exist without a centralized organizing department, but in practice many unions with professional staffs also have such departments. The number of unions that have adopted each practice is then calculated as the sum of all unions that have adopted in that year or prior ones. This assumes that unions tend not to abandon either practice, which the interviews confirmed.

\subsection{Control variables}

Disaffiliation is a binary variable set to one for unions in the years (if any) when they were outside the AFL-CIO. The direction of its effect is not hypothesized. Core industries, the basis of a union's jurisdiction, were identified for each union using three steps. First, the industries targeted by each union in the 1960s, the period in the sample data with the most unions and greatest supposed adherence to the jurisdiction scheme, were tabulated and the most common industries flagged. Second, the list of industries for each union was checked against a brief history of the union (Hildebrand 1979) to look for missing core industries and early outliers. Doing so generated a tentative list of core industries for each unit that existed by 1970. Third, these lists were updated to account for mergers and amalgamations so that the expanded unions would "inherit" all the core industries of their predecessors. Thus for

example when the United Food and Commercial Workers first appears in the data set in 1979, it has listed as core industries all those claimed by the United Packinghouse Workers, the Amalgamated Meat Cutter and Butcher Workers and the Retail Clerks International 
Association, who joined to create the UFCW that year.

I assume that a union suffers penalties when it enters a new jurisdiction. There are however system-level implications of jurisdictional invasion that resemble the trade-offs between legitimation and competition seen in population ecology (Hannan \& Freeman 1987). Many unions may compete within a given industry at one time. While the presence of rivals reduces the likelihood of success for any one union, the fact that so many have targeted a given industry also suggests that there is something particularly appealing about that industry. Whether the number of unions active in an industry better reflects the vicissitudes of competition or the richness of the rewards is an empirical question worth investigating; no assumption about the effects of such union rivalry are made. Here union rivalry is operationalized as the number of different unions active in the targeted industry in the prior three years.

The size of industry is recorded using the BLS's Quarterly Census of Employment and Wages and industrial concentration using the Department of Commerce's four-firm concentration statistics for various SICs. Both controls emerge from industrial-relations theory: employees in growing industries have less reason to fear for their jobs if they engage in union activity (Bronfenbrenner 1996) while in less-competitive industries employers have larger surpluses to potentially share with the workforce (Dunlop 1958, Galbraith 1968). Larger bargaining-unit size has long been hypothesized to lower the likelihood of organizing success (see for example Flanagan (1989)) due to free-rider problems (Olson 1965), while larger unions are thought to increase success both because a large membership is a palpable demonstration of a union's clout or resources and because size, as a product of past success, is a proxy for unobserved union organizing ability (Hannan \& Freeman 1988, Jarley, Fiorito \& Delaney 1997). Unit size here is controlled for by including the number of eligible voters in the model. The log of Union size for affiliated unions is taken from membership figures reported in the AFL-CIO's biennial conference proceedings, with membership changes in even-numbered years assumed to be linear between reports. Membership figures for non- 
affiliated unions are taken from those unions' own national conventions, which also tend to be biennial. The legal environment in the form of the presence or absence of right-to-work laws is coded based on the data gathered on the National Right to Work Foundation's web site. While such laws generally make union organizing more difficult, they usually have the greatest effect on convincing organizers to terminate a drive before election rather than to go to a vote and lose. Thus the drives in such states that do go to election are a self-selected sample in which it is reasonable to assume that the organizers had grounds for expecting success (Ferguson 2008). Finally the number of drives per year is included to control for the fact that unions that engage in more organizing activity are likely to appear more diverse as a function of their level of activity. Table 1 presents summary statistics for the variables used in the analysis.

[Table 1 about here.]

\section{Results}

I estimate probit models in which union organizing drives are the units of observation. The dependent variable in these models is victory in the representation election. Because there are many observations for each union and because unobserved heterogeneity among unions' organizing tactics is likely, I also estimate fixed-effects probits that control for the union. In all models the standard errors are clustered by union.

An important alternative explanation for weakened effects of jurisdiction is that patterns of interaction between workers, organizers and unions have no relationship to the category scheme. Rather, the jurisdictional system simply collapsed after 1980, and without that external constraint voters were as happy to vote for one union as another. This explanation would imply that, once time is controlled for, unions' adoption of centralized organizing departments should be insignificantly related to election success. To test this alternative explanation, I estimate models that include fixed effects for each year. In this model, the 
number of unions centralized will drop out because it varies solely with time, but the interaction between number centralized and the other variables of interest can still be estimated.

Tables 2 and 3 report regression results. Model I presents the estimated coefficients for the model controls. Disaffiliation has a negative coefficient, which suggests that the reputational or other penalties for operating outside jurisdiction outweigh any benefits from being "free" of no-raiding agreements. As hypothesis 1 predicted, core industry has a positive coefficient; workers are more likely to vote for unions based in their own industries. Union rivalry also has a positive coefficient, which suggests that multiple unions' operating in a given industry is more a sign of low-hanging fruit than of desperate competition. The other controls move in the directions that industrial relations and sociological theory predict. Even with just the controls present, the effect of the number of drives launched per year is essentially a well-estimated zero.

[Table 2 about here.]

Model II introduces organizing diversity. The model supports hypothesis 2 that diversification carries with it a substantial penalty. The quadratic term suggests that these penalties do not disappear until a union's organizing diversity ranges above .78 This is about the level reached by the ILWU and the UAW, two of the most diversified unions in the sample, in figure 3. Model III introduces the indicator variable for whether the union has adopted a centralized organizing department and the count of other unions that have also done so. Because the number of unions with centralized organizing is near zero in 1961 and rises over time while union win rates fall before 1982 and then rise (as shown in figure 2), the square of number centralized is included to capture this non-linearity. Voters are more likely to vote for unions with centralized organizing departments, consonant with hypothesis 3 . The number of unions with centralized bargaining has a positive effect above 7.71, i.e., after eight unions switched to centralized bargaining. The AFL-CIO crossed this threshold in 1988.

Models IV and V introduce interaction terms between diversification, centralization and the number of unions centralized. The two-way interactions in model IV are not by them- 
selves significant. This makes sense, insofar as some of the variables are hypothesized to have different effects under different conditions. Consider the interaction between centralization and diversification, for example. Much of the revitalization literature focuses on strategic campaigns among largely unorganized workers (Clawson 2003, Milkman 2006). In these campaigns, the centralized department is expected to be associated with smaller penalties for organizing across jurisdictions. By contrast, centralized organizing was a strong tactic for unions like the Steel and Electrical workers in the 1960s and 1970s, but those unions focused on their own jurisdictions, and had very little success in the broader economy. Combining drives from the two eras in a single model washes these countervailing effects out. Similar reasoning can be applied to the other two-way interactions.

Including the three-way interaction in model $\mathrm{V}$ clarifies the underlying patterns. For example, voters were less likely to vote for a diversely organizing union with a centralized organizing department when such a department was a rare organizational feature. This finding supports hypothesis 4. Adopting reforms also matters: contra hypothesis 5, workers did not become more willing to vote for just any diversely organizing union as the organizational reforms spread, as seen by the non-significant interaction between diversification and the number centralized. Instead, and in line with hypothesis 6 , voters were only more likely to vote for diverse unions that had reformed their organizing practices. Finally, voters were actually less likely to vote for centralized organizers later in the period, if that union's organizing remained concentrated.

Figure 6 shows these findings graphically. Panel A reproduces figure 4, which showed the estimated effect of diverse organizing on the probability of success for different years. That association is problematic because it conflates the union organizational reforms that are of primary interest here with any other time-varying effects. Panel B therefore re-scales the $x$-axis to show changes in the number of unions that have adopted centralized organizing, rather than time. The interaction between diversification and the number centralized is visible here, in the line's positive slope. However, this effect conflates two different patterns 
of diverse organizing: that done by "revitalized" unions and that done through traditional organizing practices. Panel $\mathrm{C}$ therefore splits the pooled effect into two parts, showing the three-way interaction between diversification, the number centralized and the adoption of centralized organizing. Panel $\mathrm{C}$ shows that diverse organizing is only associated with better win rates over time for those unions that had adopted centralized organizing practices, as hypothesized. Workers were no more likely to vote for unions that diversified their organizing without centralizing; these "opportunist" unions were even less likely to win than a baseline union that remained decentralized and concentrated on organizing in its core jurisdiction. This penalty, which can be thought of as reflecting that "weird" case where a traditional business agent approaches a group of workers in an unrelated industry, does not diminish with time.

[Figure 6 about here.]

Panel C contains an anomaly: it shows that voters were always more likely to vote for diversely organizing unions if they had centralized organizing departments, which is not hypothesized. This apparent benefit however is an artifact of comparing all centralized to all non-centralized unions. All of the estimated models predict that centralization by itself has a significant positive effect on win rates, per hypothesis 3. Thus the better comparison is between centralized organizers who focused on their own jurisdiction and centralized organizers who targeted workers in many industries. Panel D therefore breaks out centralized organizing by diversification. When few unions have centralized their organizing departments, centralized unions that organize diversely win more often than decentralized unions, but less often than centralized unions that concentrate their organizing. Diversification thus still carried a penalty among this group, per hypothesis 4 . Yet the gap between these unions and the "merely centralized" shrinks over time, such that by 1992 (Referring back to the corresponding point on the $x$-axis of figure 4) unions that are centralized and diverse - unions, I have argued, that resemble those championed in the union-revitalization literature -are more likely to win organizing drives than any other group. After 1992, therefore, unions 
that have adopted structural reforms are expected to see an unambiguous benefit from diverse organizing.

Tables 3 and 4 presents several robustness checks on these results. In model I of table 3 I introduce union fixed effects. ${ }^{9}$ The variables of interest remain unchanged; the effects found in model $\mathrm{V}$ of table 2 are not just due to unobserved heterogeneity in union tactics. Model II introduces year fixed effects, in order to control for other, unobserved contemporary trends that might affect workers' general proclivity to vote for unions based outside their industries. As discussed, the number centralized drops out of this model, because it varies by year and thus cannot be independently identified from the year fixed effects. Yet the other coefficients remain significant and of comparable size. This suggests that the results documented in figure 6 are not simply picking up an unobserved time trend or union variation but instead reveal a meaningful correlation among these variables. In particular, there is no evidence in these patterns of voter behavior to suggest a sharp break with past practice in 1982 , the point at which the union-side research suggest things entered a crisis. New patterns of union-voter interaction emerged more gradually and were only widespread enough to change the expected effects of diversification by the early 1990s, nearly a decade later.

[Table 3 about here.]

The most likely alternative reason why unions would benefit from diverse organizing is that some unobserved feature of the union or of its organizing tactics makes the union more likely to win any organizing drive, and thus makes the correlation between centralization and diversification spurious. If success merely breeds success, in other words, then unions that tend to win for other reasons will tend to win in new industries, but not because of the structural reforms hypothesized here to matter. To test this possibility, model III includes for each observation the union's lagged average win rate for the prior three years. ${ }^{10}$

\footnotetext{
${ }^{9}$ Because including these fixed effects produces no substantive changes in the coefficients on the control variables, I do not report them here. Disaffiliation, which has little within-union variation, becomes insignificant in these models.

${ }^{10}$ The win rate is calculated for the three years prior to the election date, not the preceding three calendar years. This allows the win rate to be identified independently of the year fixed effects. Lags from two to five
} 
Unsurprisingly, unions that have been more likely to win in the past are more likely to win in the present; the average win rate both has a large positive coefficient and increases the model's pseudo- $\mathrm{R}^{2}$. The variables of interest however retain their significance net of the win rate's inclusion.

Table 4 presents a convergent test of the mechanism theorized here. If stable social relations helped to reproduce the unions' observed industrial jurisdiction scheme by helping to direct potential union members toward the "appropriate" union and away from other ones, and if those stable social relations were a product of higher union density in certain industries, then workers' willingness to vote for unions that organize across industries should vary with union density in their own industry. That is, an interaction between industrial density and the core-industry variable should be positive. ${ }^{11}$ Data on union densities by industry is limited to the years after 1982, because the Bureau of Labor Statistics only added questions about union affiliation to the Current Population Survey beginning with its 1983 round. There have nonetheless been substantial changes in union density in many industries since 1983, so sufficient variation exists to estimate effects.

Model I of table 4 reproduces the control variables from table 2 for this subset of the original data. All the coefficients have similar magnitudes in this post-1982 sample, though union rivalry, right-to-work laws and the number of drives per year do not reach statistical significance. Model II introduces union density in the focal industry of the organizing drive. The coefficient on density is positive, which makes intuitive sense, not least because any unobserved propensity of workers in an industry to vote for unions would be reflected in the industry's union density. Model III interacts density with the core-industry indicator. This interaction term is significant; more strikingly, the estimated coefficient on core industry in this model is only about half the size of that in model II. Taken together, these results do suggest that at least part of the propensity for workers in an industry to favor unions that have jurisdiction over their industry is a function of density.

years produce similar results.

${ }^{11}$ I am grateful to an anonymous reviewer for this observation. 
[Table 4 about here.]

Models IV and V introduce union and year fixed effects to this specifiation. (Because the CPS measures union density by industries annually, the two sets of fixed effects cannot be introduced in the same model.) Model IV can be interpreted much like model I from table 3 , as controlling for union-specific sources of unobserved heterogeneity. The main effect of core industry is larger in this model, which reflects that there is some variation across unions in workers' willingness to endorse organizing attempts by outsiders. The interaction between

density and core industry remains significant and positive, though. Similarly, model V can be interpreted as examining between-union variation within years. Here too there is evidence of an interaction between industrial density and workers in that industry being less willing to vote for unions from other jurisdictions - and, conversely, greater openness to outsiders among workers in industries with lower union densities.

\section{Discussion and conclusion}

American labor unions before 1980 had many of the characteristics of categorization schemes that recent research has emphasized, including a division of a resource space into niches (by industry), specialist organizations in most of those niches and workers who by their votes preferred unions that were more specialized by industry. If we only had data on that historical period, it would be natural to presume that such a stable classification scheme was generated by the cognitive mechanisms that the theory has stipulated. We have data on what came afterward, though, and I have argued that cognitive mechanisms describe American unions after 1980 poorly. In emphasizing the contrast between these two eras, I hope to underline the risk in observing a stable categorization scheme and inferring that actors reproduce it by consciously evaluating organizations against the ideal-typical categories the scheme comprises.

Union members actually spent very little time and effort evaluating the relative merits of 
specialist and generalist unions in the past. Instead, the typical group of workers who were interested in unionization were likely to be funneled, via pre-existing social relationships in their industries, to a particular union. The absence of choice in the union organizing process is more important for explaining the reproduction of categories than is the evaluation of competing claims. Furthermore, once the political and employer assault on organized labor got underway in the 1980s, workers whose traditional patterns of interaction had been disrupted were quick to disregard fidelity to the old industrial jurisdictions, if doing so meant that they could link up with an organization that had a better chance of winning an organizing campaign under hostile circumstances. Workers became more willing to vote for more diverse unions, but not blindly so. Rather than simply voting in greater numbers for diverse unions over time, which would be consistent with a simple collapse of jurisdiction or a change in voters' preferences toward diversification for its own sake, voters rewarded those unions that had undertaken the structural reforms associated with corporate campaigns and other strategic organizing practices (Walker, Martin \& McCarthy 2008). Those unions, incidentally, organized across more industries. Jurisdiction, an epiphenomenon of older union-worker interaction patterns, has faded.

In union organizing drives, a key role has been the organizer and the unions' structuring of that function, as other work devoted to rebuilding the labor movement has suggested (Milkman \& Voss 2004, Fantasia \& Voss 2004). Most recent work on classification has paid little attention to internal organizational features such as these. Nor has that work explicitly theorized why structures of interaction should influence whether and how actors use for classification, save as an identification strategy. Yet research on categorization has deep if under-emphasized roots in network theory, as evidenced by the importance of the mediated market in Zuckerman's (1999) early formulation. This study proposes that uncovering different role structures and how they reinforce or erode patterns of interaction is a swift and deep channel for this research stream to follow. By contrast, contemporary theories of categorization assume that the process is mainly cognitive and thus bracket social interaction. 
They shift focus to the categories themselves and leave unexplored how audience members would agree on the categorization of candidates in the first place. Such approaches have little to say to the "roles from networks" tradition that White and his co-authors developed in structural sociology (White, Boorman \& Breiger 1976, Boorman \& White 1976).

One implication of this study though is that the change in union voting patterns after the early 1980s resulted in part from changed interactions between workers and unions, in particular the declining familiarity of workers with unions and the increasing rarity of union activity in any given industry. Future research into changes in category schemes should look for such changes in social-network patterns. The goal in doing so would be to know whether particular two-mode network structures tend to encourage, reinforce or erode category schemes. Simulation work seems an obvious way to develop some theoretical propositions on this front.

One theoretical and one empirical caveat around these findings should be noted. Theoretically, the firm is also an important actor within the union-organizing process. The discussion outlined above does not assume that firms are unimportant but rather assumes that there has been an across-the-board increase in employers' hostility to unionization in the United States over the last thirty years. Such an assumption is broadly consistent with much labor research (Freeman \& Kleiner 1990, Bronfenbrenner \& Juravich 1995, Cohen \& Hurd 1998, Lichtenstein 2002, Lafer 2005). Testing specific hypotheses about the level of employer resistance requires different data, however, much of which is unavailable for most of the time period under consideration. Empirically, this study posits mechanisms based on the thoughts and actions of potential union members, but draws those mechanisms from interviews with union organizers. The actual observation of demand-side behavior is therefore indirect. Yet even an indirect test is a step forward in the literature on union-organizing strategies. Several seminal studies in this area have also relied on the experiences and ideas of organizers to describe voter behavior (Bronfenbrenner 1997, Voss \& Sherman 2000, Bronfenbrenner \& Hickey 2004). My tactic has been to reason out the implications of those 
organizers' ideas for voting behavior and to test whether those implications hold in the election data, which is the most direct measurement available. They do. Its chief contribution to the research on labor-union revitalization therefore is its quantitative support for many of that research's qualitative predictions.

AFL-CIO unions developed a strong jurisdictional system that gave them leverage to bargain agreements with employers that benefited their members. Members in turn supported the jurisdictional system. By voting against unions that were not specialized in their industries more often than against unions that were, potential members did not endorse specialization within a jurisdiction per se but rather cast their lot with unions that, because of their specialization, were more likely to win agreements that gave them, in Samuel Gompers's famous formulation, "More" (Currarino 2003). Members' expectations were reinforced by a role structure of organizer-worker interaction wherein local business agents who had history in and detailed knowledge of the industry - and who were often slated to negotiate with the employer - connected candidate unions to members through pre-established social channels.

Thirty years ago, this system broke down. Specialization within an industry went from being a winning strategy for unions to being a recipe for decline. Unions' new organizing tactics, often focusing on multiple establishments in unfamiliar industries that were targeted by teams of professionally-trained organizers, appealed to new members who had few preestablished social contacts with unions. Such organizing was by its nature more portable across industries. The stability of this new pattern of relations is open to question. Industry knowledge, particularly of the culture of industry and the details of the work process that were learned on the job and determined pay and performance (Doeringer \& Piore 1971), is inherently less "abstractable" (Abbott 1988) and portable than corporate research and professional organizing. Today, when some unions have changed their style of organizing and others have not, these new tactics are a useful way to appeal to workers in different industries. If most unions began to organize in the "new" way, then such portable skills 
would be less useful as a way for a union to differentiate itself. At that point, the social ties that such many unions have forged or are trying to forge with new groups of workers may come once again to play a dominant role in guiding workers to particular unions - though by that point it could be easy in retrospect to say that it was something about these unions' bargaining tactics, say, that made them appeal to specific groups of workers.

Thinking through such a change does suggest one reason why cognitive explanations for categorization are so compelling in sociological research. A category scheme that is stable in the long run should have as its basis of value some characteristic like deep industry knowledge that is inherently difficult to abstract. In a stable system, people will be seen making choices that reflect durable, "concrete" differences between organizations. Absent change in the system it is easy to assume that they make such distinctions for their own sake. Doing so though leaves unexplained why the categories that audiences use sometimes completely change (Ruef 1999) or why a particular scheme is agreed upon in the first place (Lounsbury \& Rao 2004). As with many things in organizations, the value assumed to inhere in a category scheme is usually implicit, and it is only when organizational practices are threatened and must change that the justifications for using them become explicit (Perrow 1986, Powell \& DiMaggio 1991, Barley \& Kunda 1992).

This is why upheaval in a system of organizations like labor unions is so important to consider. Organizational crises are often fruitful for research but rarely fruitful for the organizations themselves. The collapse of the American labor movement has been a calamity. That its struggles to reinvent itself can give researchers insight into the workings of social categorization is cold comfort indeed. Whether and how that movement will rebuild itself is one of the great looming questions of social science and public policy. This study points to how some changes that unions have made in the medium-term, such as the centralization of organizing and the training of full-time, professional organizing staffs, have apparently been productive, albeit within a context where even the high-performing unions have expanded their membership but slightly. Though the old is dying, the new is clearly not yet born. It is 
almost impossible with one system, even one involving scores of unions over scores of years, to know what elements of past behavior may predict future performance. The most urgent next step in this research therefore is to conduct similar explanations in different organizational settings to build the breadth of comparisons that would make such predictions feasible.

\section{References}

Abbott, Andrew. 1988. The System of Professions: An Essay on the Division of Labor. Chicago: University of Chicago Press.

Barbash, Jack. 1983. The Elements of Industrial Relations. Madison, WI: University of Wisconsin Press.

Barley, Stephen R. \& Gideon Kunda. 1992. "Design and Devotion: Surges of Rational and Normative Ideologies of Control in Managerial Discourse." Administrative Science Quarterly 37:363-400.

Bearman, Peter S., James Moody \& Katherine Stovel. 2004. "Chains of Affection: The Structure of Adolescent Romantic and Sexual Networks." American Journal of Sociology 110(1):44-91.

Berger, Peter \& Thomas Luckmann. 1966. The Social Construction of Reality: A Treatise on the Sociology of Knowledge. Garden City: Doubleday.

Block, Richard N. \& Benjamin W. Wolkinson. 1986. Delay in the Union Election Campaign Revisited: A Theoretical and Empirical Analysis. In Advances in Industrial and Labor Relations, ed. David B. Lipsky \& David Lewin. Vol. 3 Greenwich, CT: JAI Press pp. 43-81.

Boorman, Scott A. \& Harrison C. White. 1976. "Social Structure from Multiple Networks. II. Role Structures." American Journal of Sociology 81(6):1384-1446.

Bronfenbrenner, Kate. 1996. Final Report: The Effects of Plant Closing or Threat of Plant Closing on the Right of Workers to Organize. Technical report North American Commission for Labor Cooperation.

Bronfenbrenner, Kate. 1997. "The Role of Union Strategies in NLRB Certification Elections." Industrial and Labor Relations Review 50(2):195-212.

Bronfenbrenner, Kate, ed. 1998. Organizing to Win: New Research on Union Strategies. Ithaca, NY: ILR Press.

Bronfenbrenner, Kate \& Robert Hickey. 2004. Changing to Organize: A National Assessment of Union Strategies. in Milkman \& Voss (2004).

Bronfenbrenner, Kate \& Tom Juravich. 1995. The Impact of Employer Opposition on Union Certification Win Rates: A Private/Public Sector Comparison. Technical Report 113 Economic Policy Institute.

Brudney, James J. 2005. Contractual Approaches to Labor Organizing: Supplanting the Election Paradigm? In Proceedings of the 57th Annual Meeting. Vol. 57 of Labor and Employment Relations Association Labor and Employment Relations Association pp. 106-113.

Chaison, Gary N. \& Dileep G. Dhavale. 1990a. "The Changing Scope of Union Organizing." Journal of Labor Research 11(3):307-322.

Chaison, Gary N. \& Dileep G. Dhavale. 1990b. "A Note on the Severity of the Decline in Union Organizing Activity." Industrial and Labor Relations Review 43(4):366-373.

Clawson, Dan. 2003. The Next Upsurge: Labor and the New Social Movements. Ithaca, NY: Cornell University Press.

Clemens, Elisabeth S. \& James M. Cook. 1999. "Politics and Institutionalism: Explaining Durability and Change." Annual Review of Sociology 25:441-466. 
Cohen, L. \& Richard Hurd. 1998. Fear, conflict and union organizing. In Organizing to Win: New Research on Union Strategies, ed. Kate Bronfenbrenner, Sheldon Friedman, Richard Hurd, R. Oswald \& R. Seeber. Ithaca, NY: ILR Press pp. 181-196.

Collins, Randall. 1981. "On the Microfoundations of Macrosociology." American Journal of Sociology 86(5):984-1014.

Cornfield, Daniel B. 1987. Decline and Diversification: Causes and Consequences for Organizational Governance. In Research in the Sociology of Organizations. Vol. 5 Greenwich, CT: JAI Press pp. 187-216.

Craft, James A. 1991. "Unions, Bureaucracy, and Change: Old Dogs Learn New Tricks Very Slowly." Journal of Labor Research 12(4):393-405.

Cumbler, John T. 1989. A Social History of Economic Decline: Business, Politics, and Work in Trenton. New Brunswick, NJ: Rutgers University Press.

Currarino, Rosanne. 2003. "The Politics of 'More': The Labor Question and the Idea of Economic Liberty in Industrial America." Journal of American History 93(1):17-36.

Delaney, John, Paul Jarley \& Jack Fiorito. 1996. "Planning for Change: Determinants of Innovation in U.S. National Unions." Industrial and Labor Relations Review 49:597-614.

Doeringer, Peter \& Michael Piore. 1971. Internal Labor Markets and Manpower Analysis. Lexington, MA: Heath.

Dunlop, John T. 1958. Industrial Relations Systems. New York: Holt.

Dunlop, John T. 1988. Labor Markets and Wage Determination: Then and Now. In How Labor Markets Work, ed. Bruce E. Kaufman. Lexington, MA: Lexington pp. 47-87.

Durkheim, Émile. 1982. The Rules of Sociological Method and Selected Texts on Sociology and Its Method. New York: Free Press. Edited by Steven Lukes.

Eren, Ozkan. 2007. "Measuring the Union/Non-Union Wage Gap Using Propensity Score Matching." Industrial Relations 46(4):766-780.

Espeland, Wendy Nelson \& Mitchell L. Stevens. 1998. "Commensuration as a Social Process." Annual Review of Sociology 24:313-343.

Fantasia, Rick \& Kim Voss. 2004. Hard Work: Remaking the American Labor Movement. Berkeley, CA: University of California Press.

Farber, Henry S. \& Bruce Western. 2002. "Ronald Reagan and the Politics of Declining Union Organization." British Journal of Industrial Relations 40(3):385-401.

Ferguson, John-Paul. 2008. "The Eyes of the Needles: A Sequential Model of Union Organizing Drives, 1999-2004." Industrial and Labor Relations Review 62(1):3-21.

Fiorito, Jack, Paul Jarley \& John Thomas Delaney. 1995. "National Union Effectiveness in Organizing: Measures and Influences." Industrial and Labor Relations Review 48(4):613-635.

Flanagan, Robert J. 1989. "Compliance and Enforcement Decisions under the National Labor Relations Act." Journal of Labor Economics 7(3):257-280.

Freeman, Richard B. 1985. "The Effect of the Union Wage Differential on Management Opposition and Union Organizing Success." NBER Working Paper No. W1748.

Freeman, Richard B. \& Morris M. Kleiner. 1990. "Employer Behavior in the Face of Union Organizing Drives." Industrial and Labor Relations Review 43(4):351-365.

Frymer, Paul. 2003. "Acting When Elected Official Won't: Federal Courts and Civil Rights Enforcement in U.S. Labor Unions, 1935-1985." American Political Science Review 97:483-499.

Galbraith, John Kenneth. 1968. The New Industrial State. Boston: Houghton-Mifflin. 
Ganz, Marshall. 2000. "Resources and Resourcefulness: Strategic Capacity in the Unionization of California Agriculture, 1959-1966." American Journal of Sociology 105(4):1003-1062.

Goldfield, M. 1987. The Decline of Organized Labor in the United States. Chicago: University of Chicago Press.

Griffith, Barbara S. 1988. The Crisis of American Labor: Operation Dixie and the Defeat of the CIO. Philadelphia: Temple University Press.

Hannan, Michael T. 2010. "Partiality of Memberships in Categories and Audiences." Annual Review of Sociology 36:159-181.

Hannan, Michael T. \& John Freeman. 1987. "The Ecology of Organizational Founding: American Labor Unions 1836-1985." American Journal of Sociology 92:910-943.

Hannan, Michael T. \& John Freeman. 1988. "The Ecology of Organizational Mortality: American Labor Unions, 1836-1985." American Journal of Sociology 94(1):25-52.

Hannan, Michael T., Lásló Pólos \& Glenn R. Carroll. 2007. Logics of Organization Theory: Audiences, Codes, and Ecologies. Princeton, NJ: Princeton University Press.

Hildebrand, George Herbert. 1979. American Unionism: An Historical and Analytical Survey. Reading, MA: Addison-Wesley.

Hirsch, Barry T. \& David A. Macpherson. 2004. "Union Membership and Coverage Database from the Current Population Survey." Available online at http://unionstats.com.

Hsu, Greta. 2006. "Evaluative Schemas and the Attention of Critics in the US Film Industry." Industrial and Corporate Change 15:467-496.

Hsu, Greta, Michael T. Hannan \& Özgecan Koçak. 2009. "Multiple Category Memberships in Markets: An Integrative Theory and Two Empirical Tests." American Sociological Review 74:150-169.

Huising, Ruthanne. 2008. "Working There: Managing Representations and Maintaining Autonomy through Local Presence." Manuscript, October 2007.

Isaac, Larry, Steve McDonald \& Greg Lukasik. 2006. "Takin' it from the Streets: How the Sixties Mass Movement Revitalized Unionization." American Journal of Sociology 112(1):46-96.

Jarley, Paul, Jack Fiorito \& John Thomas Delaney. 1997. "A Structural Contingency Approach to Bureaucracy and Democracy in U.S. National Unions." Academy of Management Journal 40(4):831-861.

Jepperson, R. L. 1991. Institutions, Institutional Effects, and Institutionalism. In The New Institutionalism in Organizational Analysis, ed. Walter W. Powell \& Paul J. DiMaggio. Chicago: University of Chicago Press pp. 143-163.

Katznelson, Ira. 1981. City Trenches: Urban Politics and the Patterning of Class in the United States. first ed. New York: Pantheon.

Kleiner, Morris M. 1984. "Unionism and Employer Discrimination: Analysis of 8(a)(3) Violations." Industrial Relations 23(2):234-243.

Kochan, Thomas, Harry Katz \& Robert McKersie. 1986. The Transformation of American Industrial Relations. Ithaca, NY: ILR Press.

Kovacs, Balazs \& Michael Hannan. 2010. "The Consequences of Category Spanning Depend on Contrast." Research in the Sociology of Organizations 35:175-201.

Kovacs, Balazs \& Michael T. Hannan. 2011. "Category Spanning, Distance and Appeal." Working paper.

Krislov, Joseph. 1954. "Raiding Among the "Legitimate" Unions." Industrial and Labor Relations Review $8(1): 19-29$.

Lafer, Gordon. 2005. Free and Fair? How Labor Law Fails U.S. Democratic Election Standards. Technical report American Rights at Work Washington, DC: . 
Leung, Ming D. \& Amanda Sharkey. 2010. "Out of Sight, Out of Mind: The Audience-Side Effect of Multiple Category Membership in Markets." Manuscript.

Lichtenstein, Nelson. 2002. State of the Union: A Century of American Labor. Princeton, NJ: Princeton University Press.

Lopez, Steven H. 2004. Overcoming Legacies of Business Unionism: Why Grassroots Organizing Tactics Succeed. In Rebuilding Labor: Organizing and Organizers in the New Union Movement, ed. Ruth Milkman \& Kim Voss. Ithaca, NY: ILR Press pp. 114-132.

Lounsbury, Michael \& Hayagreeva Rao. 2004. "Sources of Durability and Change in Market Classifications: A Study of the Reconstitution of Product Categories in the American Mutual Fund Industry, 1944-1985." Social Forces 82(3):969-999.

Maranto, Cheryl L. \& Jack Fiorito. 1987. "The Effect of Union Characteristics on the Outcome of NLRB Certification Elections." Industrial and Labor Relations Review 40(2):225-240.

Markowitz, Lisa \& Karen W. Tice. 2002. "Paradoxes of Professionalization: Parallel Dilemmas in Women's Organizations in the Americas." Gender and Society 16(6):941-958.

Martin, Andrew W. 2007. "Organizational Structure, Authority and Protest: The Case of Union Organizing in the United States, 1990-2001." Social Forces 85(3):1413-1435.

Martin, John Levi. 2009. Social Structures. Princeton, NJ: Princeton University Press.

McGuiness, Kenneth C. \& Jeffrey A. Norris. 1986. How to Take a Case Before the NLRB. fifth ed. Washington: Bureau of National Affairs, Inc.

Milkman, Ruth. 2006. L.A. Story: Immigrant Workers and the Future of the U.S. Labor Movement. New York: Russell Sage Foundation.

Milkman, Ruth \& Kim Voss, eds. 2004. Rebuilding Labor: Organizing and Organizers in the New Union Movement. Ithaca, NY: ILR Press.

Negro, Giacomo, Özgecan Koçak \& Greta Hsu. 2010. "Research on Categories in the Sociology of Organizations." Research in the Sociology of Organizations .

NLRB. 2007. NLRB Election Report: Six Months Summary-October 2006 through March 2007 and Cases Closed March 2007. Technical Report ER-200703 National Labor Relations Board Washington, DC: .

Olson, Mancur. 1965. The Logic of Collective Action: Public Goods and the Theory of Groups. Cambridge, MA: Harvard University Press.

Osterman, Paul. 2002. Gathering Power: The Future of Progressive Politics in America. New York: Beacon.

Pawlenko, Kye D. 2005. "Reevaluating Inter-Union Competition: A Proposal to Resurrect Rival Unionism." University of Pennsylvania Journal of Labor \&5 Employment Law 8:651-682.

Perretti, Fabrizio, Giacomo Negro \& Alessandro Lomi. 2008. "E Pluribus Unum: Domain Framing, Candidate Matching and Organizational Form Emergence in U.S. Television Broadcasting, 1940-1960." Organization Science 19:533-547.

Perrow, Charles. 1986. Complex Organizations: A Critical Essay. New York: Random House. pp. 1-48.

Perry, Charles R. 1987. Union Corporate Campaigns. Philadelphia, PA: Wharton School of Business.

Pólos, Lásló, Michael T. Hannan \& Glenn R. Carroll. 2002. "Foundations of a Theory of Social Forms." Industrial and Corporate Change 11:85-115.

Powell, Walter W. \& Paul J. DiMaggio, eds. 1991. The New Institutionalism in Organizational Analysis. Chicago: University of Chicago Press.

Rooks, Daisy. 2004. Sticking It Out or Packing It In? Organizer Retention in the New Labor Movement. in Milkman \& Voss (2004). 
Roomkin, Myron \& Richard N. Block. 1981. "Case Processing Time and the Outcome of Representation Elections: Some Empirical Evidence." University of Illinois Law Review 1:75-97.

Rosch, Eleanor. 1973. "Natural Categories." Cognitive Psychology 4:328-350.

Rosch, Eleanor \& Barbara Lloyd. 1978. Cognition and Categorization. Hillsdale, NJ: Lawrence Erlbaum Associates.

Ruef, Martin. 1999. "Social Ontology and the Dynamics of Organizational Forms: Creating Market Actors in the Healthcare Field, 1966-1994." Social Forces 77(4):1403-1432.

Santoro, Marco. 2008. "An Introduction to 'Catnets'." Sociologica 1:1-23.

Schatz, Ronald W. 1983. The Electrical Workers: A History of Labor at General Electric and Westinghouse, 1923-1960. Chicago: University of Illinois Press.

SFBMA. 1998. "The SFBMA/ILWU Partnership for Justice for the Bay Area Courier Industry." San Francisco, CA: Booklet published by the SFBMA and ILWU.

SFBMA. 2000. "A History of Bike Messengering in San Francisco." Update to the CMWC 96 information booklet; accessed online 14 May 2008 at http://www.ahalenia.com/sfbma/history.html.

Sharpe, Thresa. 2004. Union Democracy and Successful Campaigns: The Dynamics of Staff Authority and Worker Participation in an Organizing Union. In Rebuilding Labor: Organizing and Organizers in the New Union Movement, ed. Ruth Milkman \& Kim Voss. Ithaca, NY: ILR Press pp. 62-87.

Stepan-Norris, Judith \& Maurice Zeitlin. 2003. Left Out: Reds and America's Industrial Unions. New York: Cambridge University Press.

Teece, David J., R. Rumelt, G. Dosi \& Sidney Winter. 1994. "Understanding Corporate Coherence: Theory and Evidence." Journal of Economic Behavior and Organization 23(1).

Tope, Daniel \& David Jacobs. 2009. "The Politics of Union Decline: The Contingent Determinants of Union Recognition Elections and Victories." American Sociological Review 74(5):842-864.

UCW-CWA. 2002. "United Campus Workers and the CWA." Knoxville, TN: Booklet published by the CWA.

Ulman, Lloyd. 1955. The Rise of the National Trade Union: The Development and Significance of the Structure, Governing Institutions, and Economic Policies. Cambridge, MA: Harvard University Press.

Voss, Kim \& Rachel Sherman. 2000. "Breaking the Iron Law of Oligarchy: Union Revitalization in the American Labor Movement." American Journal of Sociology 106(2):303-350.

Walker, Edward T., Andrew W. Martin \& John D. McCarthy. 2008. "Confronting the State, the Corporation, and the Academy: The Influence of Institutional Targets on Social Movement Repertoires." American Journal of Sociology 114(1):35-76.

Wallace, Michael. 1989. "Aggressive Economism, Defensive Control: Countours of American Labour Militancy, 1947-1981." Economic and Industrial Democracy 10:7-34.

Warren, Dorian \& Kate Bronfenbrenner. 2007. "Race, Gender and the Rebirth of Trade Unionism." New Labor Forum .

Weick, Karl. 1979. The Social Psychology of Organizing. Reading, MA: Addison-Wesley.

Weick, Karl E. 1993. Sensemaking in Organizations: Small Structures with Large Consequences. In Social Psychology in Organizations: Advances in Theory and Research, ed. J. Keith Murnigham. Englewood Cliffs, NJ: Prentice Hall pp. 10-37.

Weick, Karl E. 1995. Sensemaking in Organizations. Thousand Oaks, CA: Sage.

White, Harrison C. 2002. Markets from Networks: Socioeconomic Models of Production. Princeton, NJ: Princeton University Press.

White, Harrison C. 2008. "Notes on the Constituents of Social Structure." Sociologica 1:1-15. Reprinted; originally gathered as class notes for Social Relations 10, Harvard University, Spring 1965. 
White, Harrison C., Scott A. Boorman \& Ronald L. Breiger. 1976. "Social Structure from Multiple Networks. I. Blockmodels of Roles and Positions." American Journal of Sociology 81(4):730-780.

Wu, Geraldine \& Gina Dokko. 2009. "Typecasting Entrepreneurs: Boundary-Crossing and Firm Performance in High-Tech Ventures." Working paper.

Wunnava, Phanindra V. 2004. The Changing Role of Unions: New Forms of Representation. New York: M.E. Sharpe.

Yu, Kyoung-Hee. 2008. Between Bureaucratic Organization and Social Movements: Careers in the Justice for Janitors Campaign PhD thesis Massachusetts Institute of Technology Cambridge, MA: .

Zuckerman, Ezra W. 1999. "The Categorical Imperative: Securities Analysts and the Illegitimacy Discount." American Journal of Sociology 104(5):1398-1438.

Zuckerman, Ezra W. 2000. "Focusing the Corporate Product: Securities Analysts and De-Diversification." Administrative Science Quarterly 45:591-619.

Zuckerman, Ezra W. 2003. "Bringing (Crude) Functionalism Back In." Essay Prepared for Spring 2003 issue of "Accounts: A Newsletter of Economic Sociology".

Zuckerman, Ezra W. 2004. "Structural Incoherence and Stock Market Activity." American Sociological Review 69(3):405-432.

Zuckerman, Ezra W. \& Hayagreeva Rao. 2004. "Shrewd, Crude or Simply Deluded? Comovement and the Internet Stock Phenomenon." Industrial and Corporate Change 13(1):171-212. 


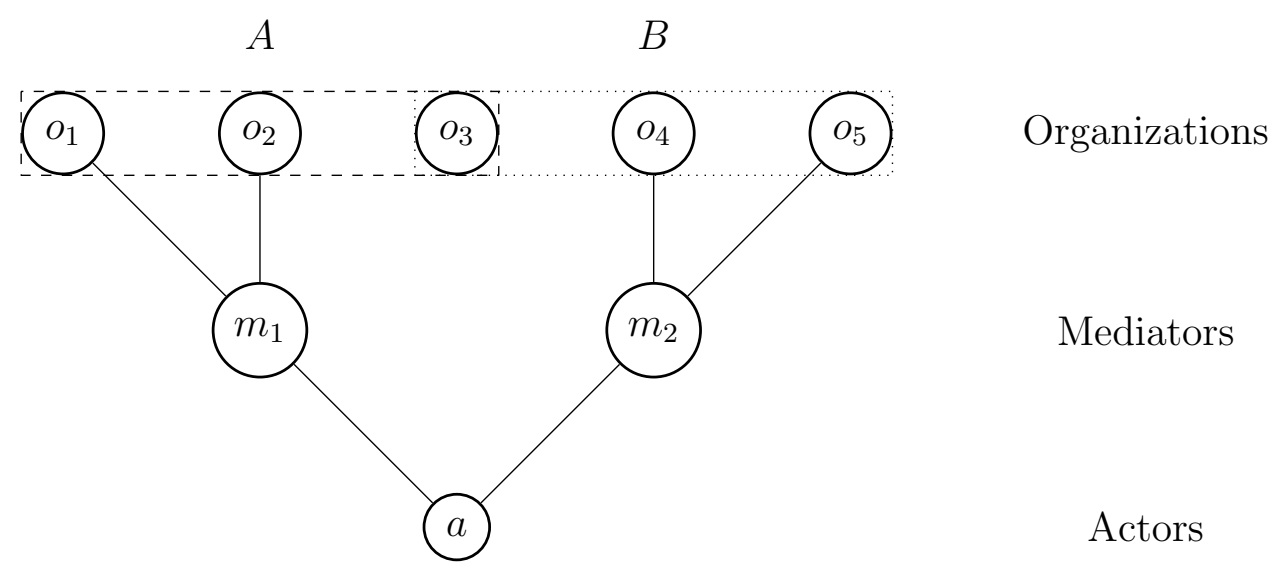

Figure 1: A social structure of categorization 


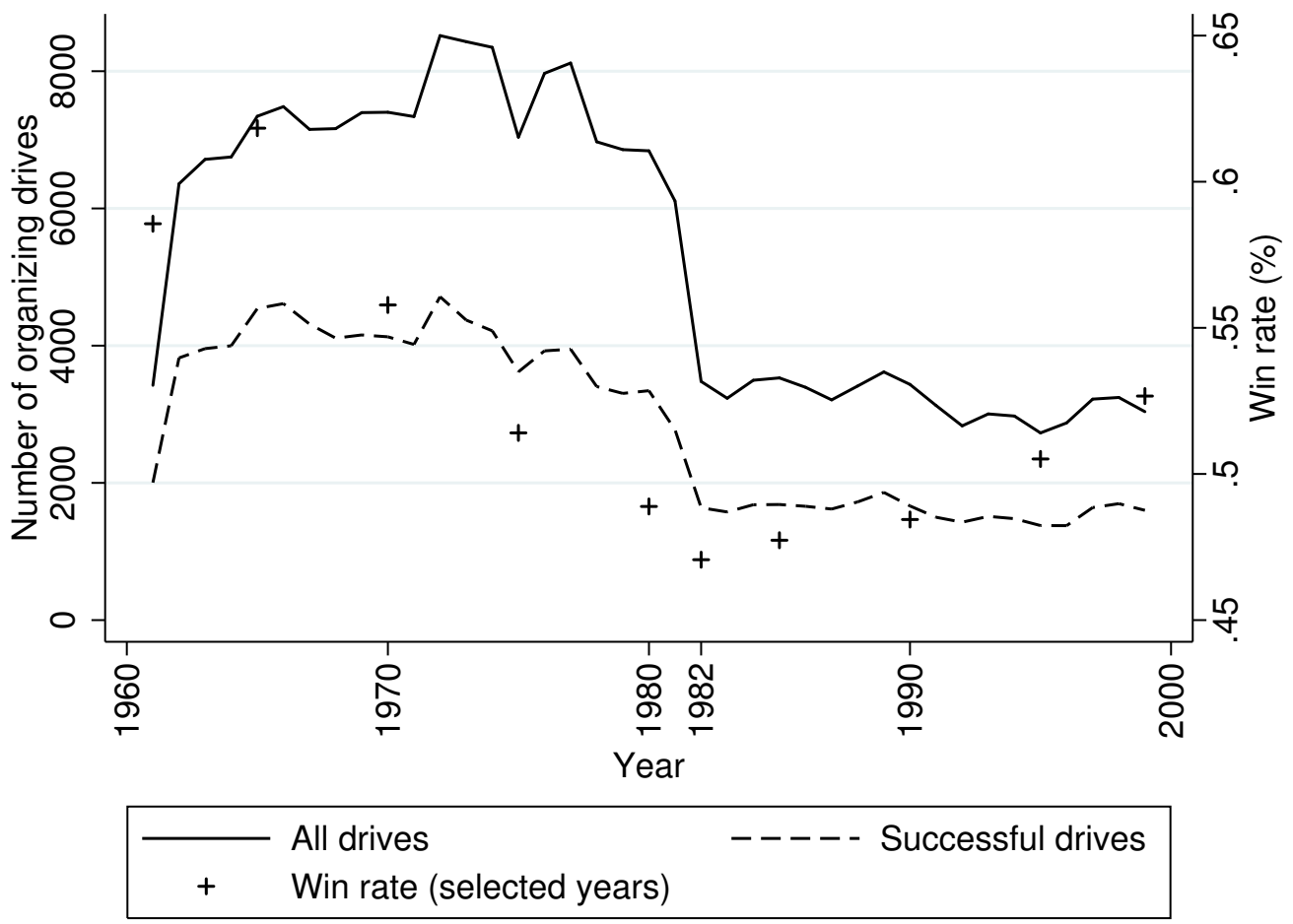

Figure 2: All and successful union organizing drives, by year, 1961-1999 


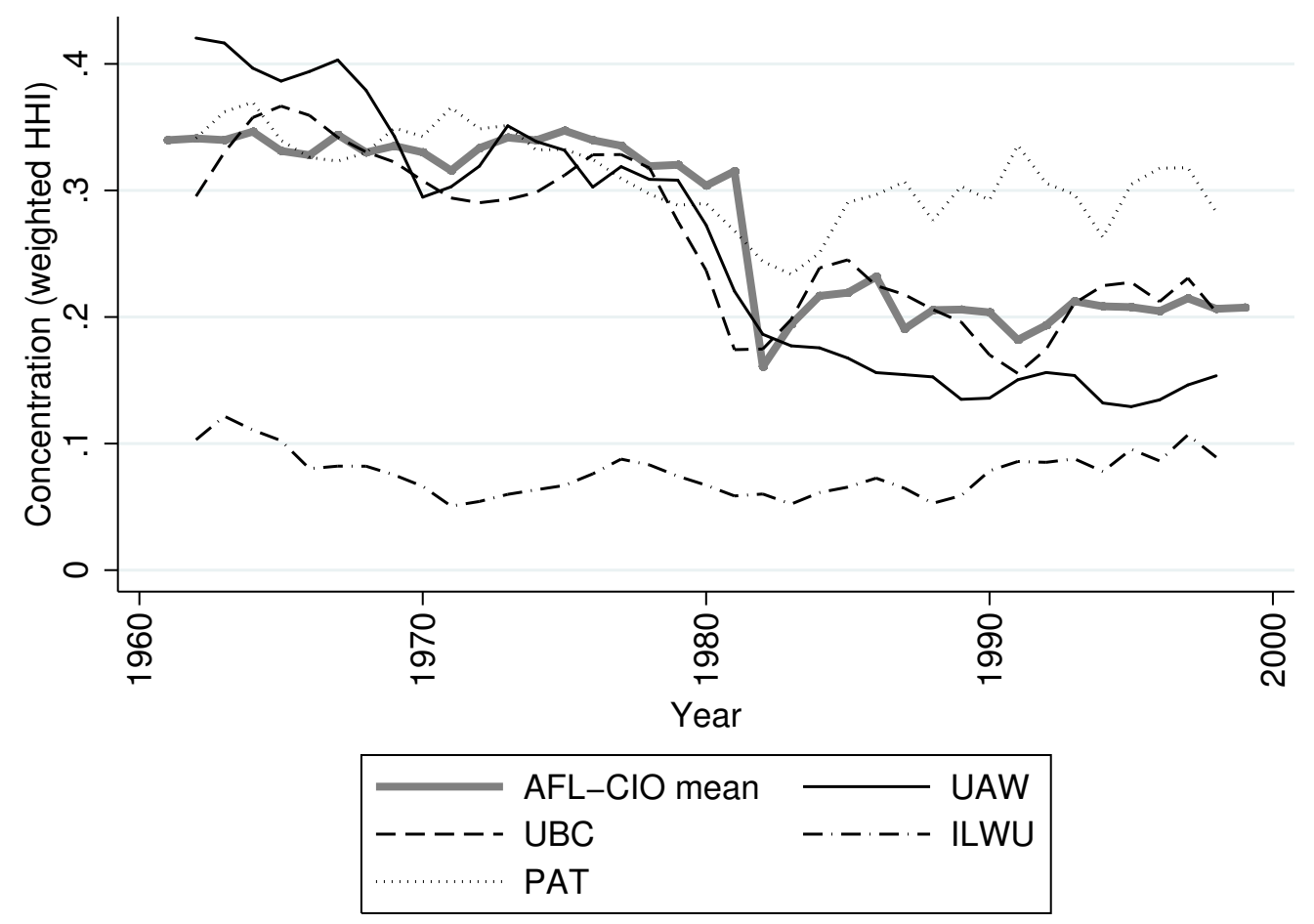

Figure 3: Industrial concentration of organizing attempts for the AFL-CIO and selected unions, 1961-1999. Union records are three-year moving averages. The ILWU was unafilliated to the AFL-CIO prior to 1988. 


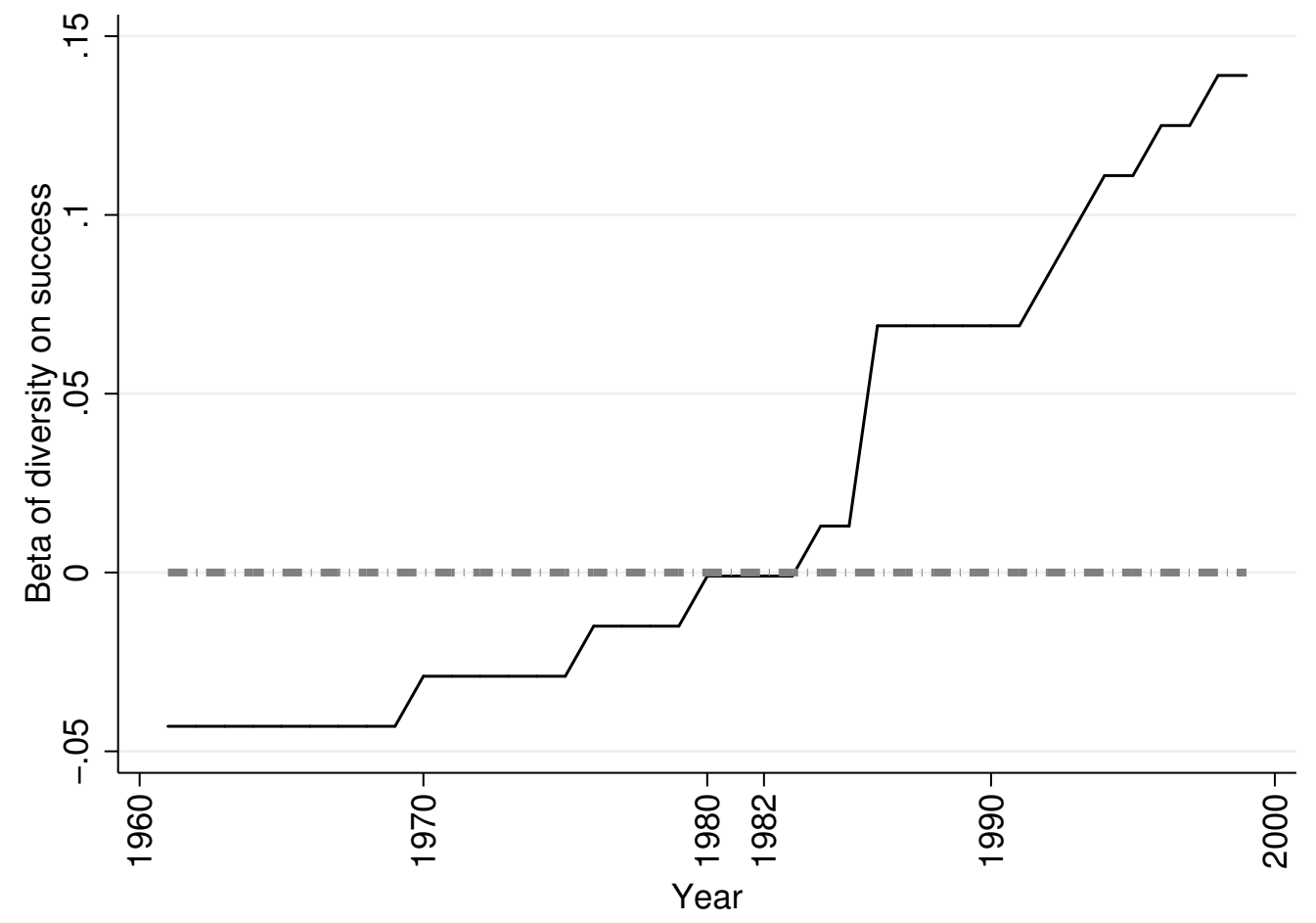

Figure 4: Estimated effect of increasing industrial diversity of union organizing drives on organizing success, 1961-1999. For each year, the calculated value is the percentage difference in the probability of winning a drive between a union whose diversity or organizing equals 1 and a union whose diversity equals zero. 


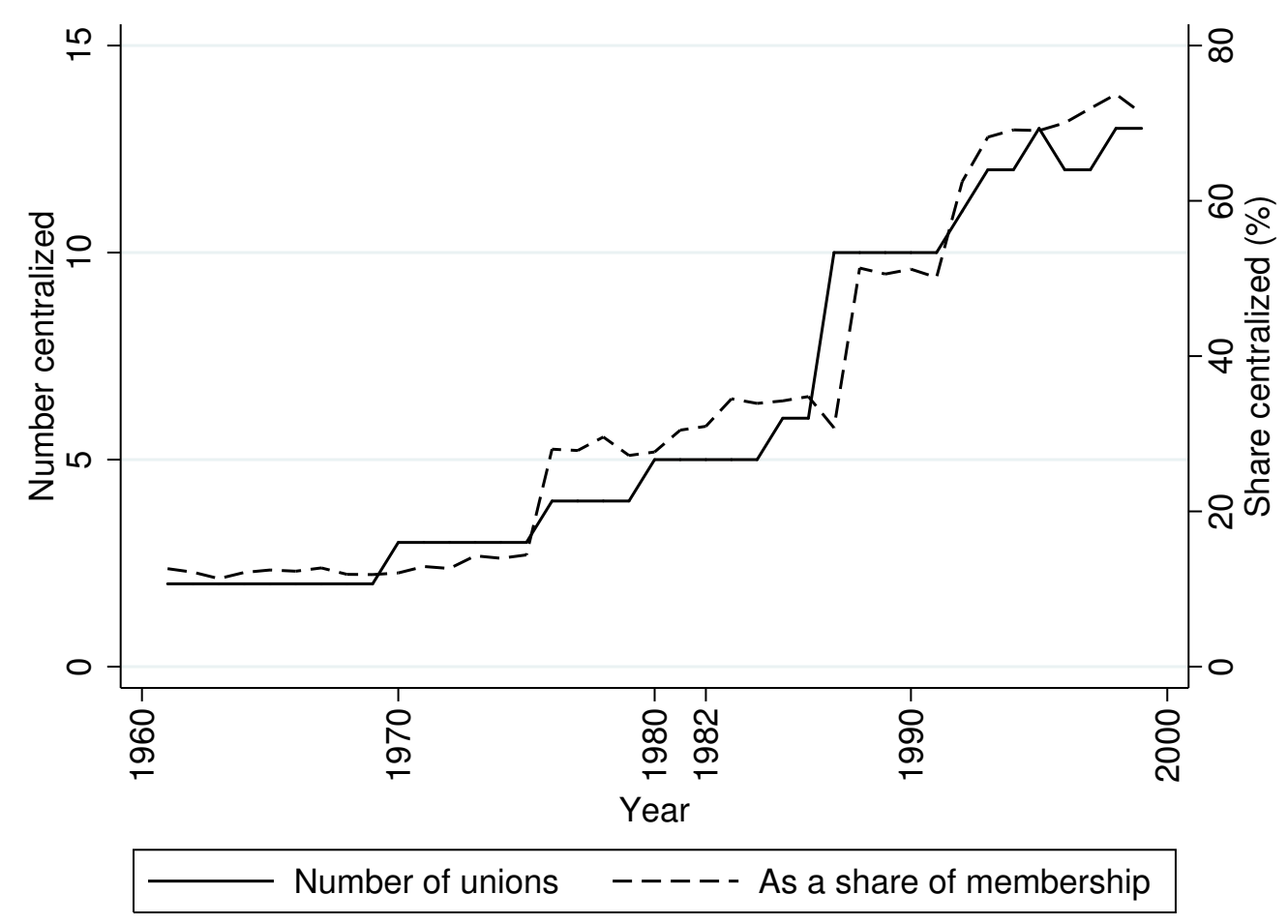

Figure 5: Unions with centralized organizing departments: raw number and as a share of AFL-CIO membership, 1961-1999. 

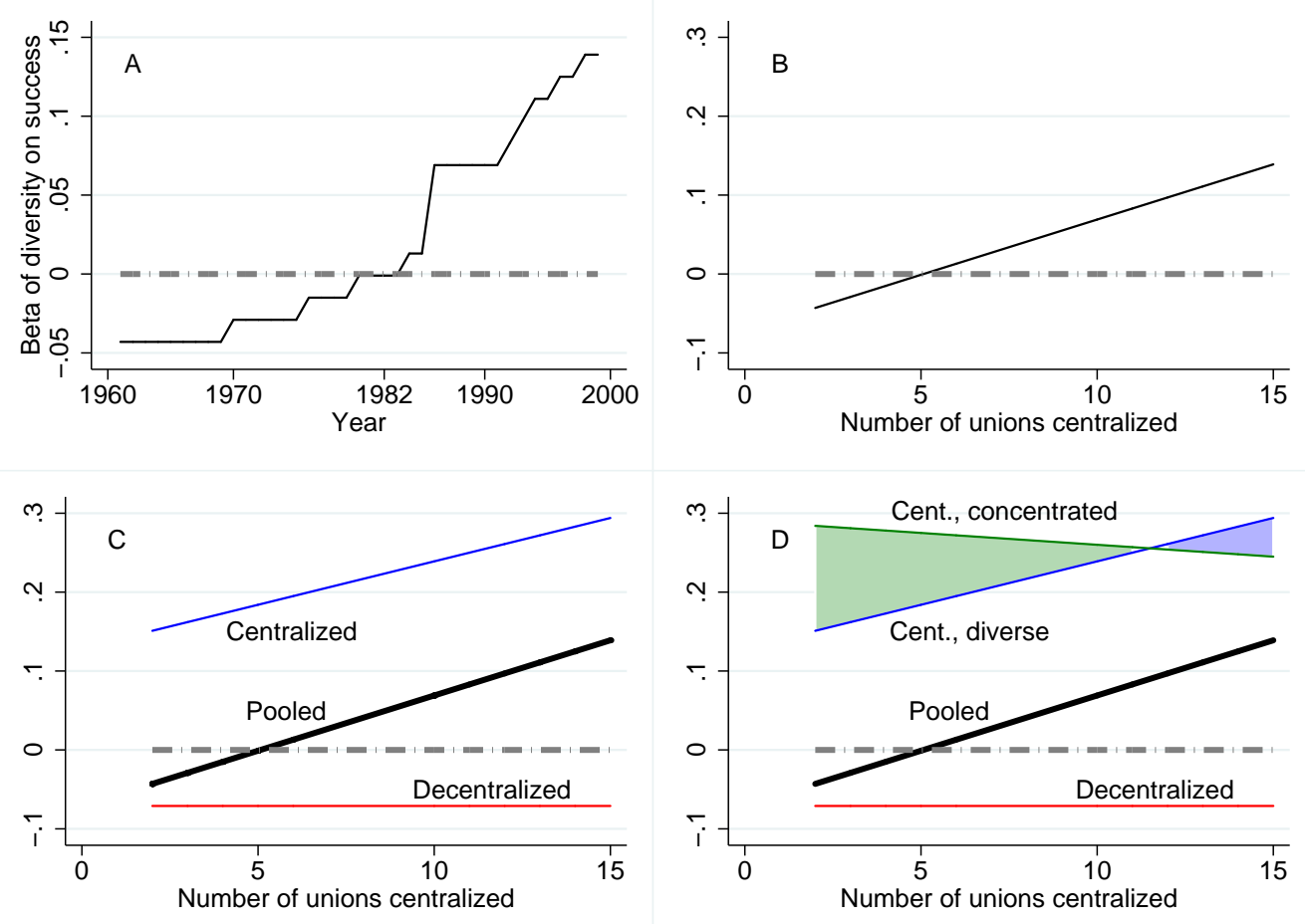

Figure 6: Estimated two- and three-way interactions between diversification of organizing, adoption of centralized organizing and the number of unions that have adopted centralized organizing. 
Table 1: Summary statistics for analysis

\begin{tabular}{lrc}
\hline \hline Variable & Mean & Std. Dev. \\
(D)iversity & 0.203 & 0.082 \\
(C)entralized & 0.217 & 0.412 \\
(N)o. cent. & \multicolumn{1}{c}{4.77} & 3.48 \\
Disaffiliated & 0.062 & 0.240 \\
Core industry & 0.651 & 0.477 \\
Union rivalry & 8.722 & 5.405 \\
Ind. size & 195.611 & 233.212 \\
Ind. conc. & 0.126 & 0.055 \\
Unit size & 3.162 & 1.641 \\
Union size & 493.524 & 354.251 \\
Right to work & 0.220 & 0.414 \\
No. drives & 143.557 & 110.045 \\
Lagged win rate & 0.516 & 0.090 \\
\hline
\end{tabular}


Table 2: Probit models of union representation-election victory, 1961-1999

\begin{tabular}{|c|c|c|c|c|c|}
\hline \multirow[t]{2}{*}{ Variable } & \multicolumn{5}{|c|}{ Model } \\
\hline & I & II & III & IV & $\mathrm{V}$ \\
\hline \multirow[t]{2}{*}{ (D)iversity } & & $-0.083^{* * *}$ & $-0.082^{* * *}$ & $-0.086 * * *$ & $-0.080^{* *}$ \\
\hline & & $(0.024)$ & $(0.026)$ & $(0.028)$ & $(0.033)$ \\
\hline \multirow[t]{2}{*}{ Diversity $^{2}$} & & $0.053^{* * *}$ & $0.054^{* * *}$ & $0.053^{* * *}$ & $0.050^{* * *}$ \\
\hline & & $(0.012)$ & $(0.011)$ & $(0.012)$ & $(0.011)$ \\
\hline \multirow[t]{2}{*}{ (C)entralized } & & & $0.046 * * *$ & $0.099^{* *}$ & $0.384^{* * *}$ \\
\hline & & & $(0.012)$ & $(0.049)$ & $(0.106)$ \\
\hline \multirow[t]{2}{*}{ (N)o. cent. } & & & $-0.185^{* * *}$ & $-0.189 * * *$ & $-0.187^{* * *}$ \\
\hline & & & $(0.007)$ & $(0.008)$ & $(0.008)$ \\
\hline \multirow[t]{2}{*}{ No. cent. $^{2}$} & & & $0.012^{* * *}$ & $0.012^{* * *}$ & $0.012^{* * *}$ \\
\hline & & & $(0.000)$ & $(0.001)$ & $(0.001)$ \\
\hline \multirow[t]{2}{*}{$\mathrm{D} \times \mathrm{C}$} & & & & -0.016 & $-0.121^{* * *}$ \\
\hline & & & & $(0.015)$ & $(0.038)$ \\
\hline \multirow[t]{2}{*}{$\mathrm{D} \times \mathrm{N}$} & & & & 0.001 & -0.001 \\
\hline & & & & $(0.001)$ & $(0.002)$ \\
\hline \multirow[t]{2}{*}{$\mathrm{C} \times \mathrm{N}$} & & & & -0.003 & $-0.008 * * *$ \\
\hline & & & & $(0.003)$ & $(0.003)$ \\
\hline \multirow[t]{2}{*}{$\mathrm{D} \times \mathrm{C} \times \mathrm{N}$} & & & & & $0.011^{* * *}$ \\
\hline & & & & & $(0.004)$ \\
\hline \multirow[t]{2}{*}{ Disaffiliated } & $-0.113^{* * *}$ & $-0.112^{* * *}$ & $-0.090 * * *$ & $-0.090 * * *$ & $-0.084^{* * *}$ \\
\hline & $(0.020)$ & $(0.020)$ & $(0.020)$ & $(0.020)$ & $(0.020)$ \\
\hline \multirow[t]{2}{*}{ Core industry } & $0.023^{* * *}$ & $0.021^{* * *}$ & 0.001 & 0.001 & 0.001 \\
\hline & $(0.009)$ & $(0.009)$ & $(0.009)$ & $(0.009)$ & $(0.009)$ \\
\hline \multirow[t]{2}{*}{ Union rivalry } & $0.006^{* * *}$ & $0.006^{* * *}$ & $0.003^{* * *}$ & $0.003^{* * *}$ & $0.002^{* * *}$ \\
\hline & $(0.001)$ & $(0.001)$ & $(0.001)$ & $(0.001)$ & $(0.001)$ \\
\hline \multirow[t]{2}{*}{ Ind. size } & $0.028 * * *$ & $0.028^{* * *}$ & $0.025^{* * *}$ & $0.025^{* *}$ & $0.026^{* *}$ \\
\hline & $(0.007)$ & $(0.007)$ & $(0.007)$ & $(0.009)$ & $(0.009)$ \\
\hline \multirow[t]{2}{*}{ Ind. conc. } & $0.043^{* *}$ & $0.043^{* *}$ & $0.039 * *$ & $0.039^{*}$ & $0.038^{*}$ \\
\hline & $(0.019)$ & $(0.019)$ & $(0.019)$ & $(0.020)$ & $(0.020)$ \\
\hline \multirow[t]{2}{*}{ Unit size } & $-0.134^{* * *}$ & $-0.134^{* * *}$ & $-0.139 * * *$ & $-0.139 * * *$ & $-0.140 * * *$ \\
\hline & $(0.003)$ & $(0.003)$ & $(0.003)$ & $(0.003)$ & $(0.003)$ \\
\hline \multirow[t]{2}{*}{ Union size } & $0.016^{* *}$ & $0.013^{*}$ & $0.013^{*}$ & $0.012^{*}$ & $0.012^{*}$ \\
\hline & $(0.006)$ & $(0.007)$ & $(0.007)$ & $(0.007)$ & $(0.007)$ \\
\hline \multirow[t]{2}{*}{ Right to work } & $0.029 * * *$ & $0.029^{*} * *$ & $0.036^{* * *}$ & $0.036^{* * *}$ & $0.036^{* * *}$ \\
\hline & $(0.011)$ & $(0.011)$ & $(0.011)$ & $(0.011)$ & $(0.011)$ \\
\hline \multirow[t]{2}{*}{ No. drives } & $0.000 * * *$ & $0.000 * * *$ & $0.000 * * *$ & $0.000 * * *$ & $0.000 * * *$ \\
\hline & $(0.000)$ & $(0.000)$ & $(0.000)$ & $(0.000)$ & $(0.000)$ \\
\hline \multirow[t]{2}{*}{ Constant } & 0.296 *** & $0.329^{* * *}$ & $0.881^{* * *}$ & $0.889^{* * *}$ & $0.878^{* * *} *$ \\
\hline & $(0.014)$ & $(0.020)$ & $(0.029)$ & $(0.032)$ & $(0.033)$ \\
\hline $\mathrm{N}$ & 86299 & 86299 & 86299 & 86299 & 86299 \\
\hline LL & -58292 & -54269 & -50114 & -50314 & -47909 \\
\hline Pseuc & 0.04 & 0.06 & 0.07 & 0.07 & 0.09 \\
\hline
\end{tabular}


Table 3: Alternative specifications for models of union representation-election victory, 19611999

\begin{tabular}{|c|c|c|c|}
\hline \multirow[t]{2}{*}{ Variable } & \multicolumn{3}{|c|}{$\overline{\text { Model }}$} \\
\hline & $\mathrm{I}$ & II & III \\
\hline \multirow[t]{2}{*}{ (D)iversity } & $-0.076^{* *}$ & $-0.071^{* *}$ & $-.054 * *$ \\
\hline & $(0.032)$ & $(0.033)$ & $(0.014)$ \\
\hline \multirow[t]{2}{*}{ Diversity $^{2}$} & $0.043^{* *}$ & $0.044^{* *}$ & $0.065^{* * *}$ \\
\hline & $(0.020)$ & $(0.018)$ & $(0.020)$ \\
\hline \multirow[t]{2}{*}{ (C)entralized } & $0.280 * * *$ & $0.292^{* * *}$ & $0.299 * * *$ \\
\hline & $(0.121)$ & $(0.126)$ & $(0.107)$ \\
\hline \multirow[t]{2}{*}{ (N)o. cent. } & $-.023^{* * *}$ & & \\
\hline & $(0.009)$ & & \\
\hline \multirow[t]{2}{*}{ No. cent. ${ }^{2}$} & $0.011^{* * *}$ & & \\
\hline & $(0.001)$ & & \\
\hline \multirow[t]{2}{*}{$\mathrm{D} \times \mathrm{C}$} & $-0.088^{* *}$ & $-0.090 * *$ & $-0.094^{* *}$ \\
\hline & $(0.043)$ & $(0.043)$ & $(0.038)$ \\
\hline \multirow[t]{2}{*}{$\mathrm{D} \times \mathrm{N}$} & -0.001 & -0.001 & -0.001 \\
\hline & $(0.002)$ & $(0.001)$ & $(0.002)$ \\
\hline \multirow[t]{2}{*}{$\mathrm{C} \times \mathrm{N}$} & $-0.018^{* * *}$ & $-0.033^{* * *}$ & $-0.025 * *$ \\
\hline & $(0.008)$ & $(0.012)$ & $(0.010)$ \\
\hline \multirow[t]{2}{*}{$\mathrm{D} \times \mathrm{C} \times \mathrm{N}$} & $0.011^{* * *}$ & $0.014^{* * *}$ & $0.009^{* *}$ \\
\hline & $(0.004)$ & $(0.005)$ & $(0.004)$ \\
\hline \multirow[t]{2}{*}{ Lagged win rate } & & & $0.889^{* * *}$ \\
\hline & & & $(0.061)$ \\
\hline Union F.E. & Yes & Yes & Yes \\
\hline Year F.E. & & Yes & Yes \\
\hline \multirow[t]{2}{*}{ Constant } & $1.061^{* * *}$ & $1.069^{* * *}$ & $0.893^{* * *}$ \\
\hline & $(0.040)$ & $(0.042)$ & $(0.225)$ \\
\hline $\mathrm{N}$ & 86299 & 86299 & 86299 \\
\hline $\mathrm{LL}$ & -47622 & -47212 & -45125 \\
\hline Pseudo $\mathrm{R}^{2}$ & 0.09 & 0.10 & 0.13 \\
\hline
\end{tabular}

Note: controls for disaffiliation, core industry, union rivalry, industry size, industry concentration, unit size, union size, right-to-work laws and the number of drives are included. Full results are available upon request. 
Table 4: Models of union representation victory controlling for union industry density, 19831999

\begin{tabular}{|c|c|c|c|c|c|}
\hline \multirow[t]{2}{*}{ Variable } & \multicolumn{5}{|c|}{ Model } \\
\hline & I & II & III & IV & $\mathrm{V}$ \\
\hline \multirow[t]{2}{*}{ Ind. density } & & $0.003^{* * *}$ & $0.004^{* * *}$ & $0.003^{* *}$ & $0.003^{* * *}$ \\
\hline & & $(0.001)$ & $(0.001)$ & $(0.001)$ & $(0.001)$ \\
\hline \multirow[t]{2}{*}{ Density $\times$ Core } & & & $0.002^{* *}$ & $0.003^{* *}$ & $0.012^{* *}$ \\
\hline & & & $(0.001)$ & $(0.001)$ & $(0.004)$ \\
\hline \multirow[t]{2}{*}{ Core industry } & $0.027^{* *}$ & $0.038^{* *}$ & $0.016^{* *}$ & $0.066^{* *}$ & $0.009 *$ \\
\hline & $(0.010)$ & $(0.018)$ & $(0.007)$ & $(0.033)$ & $(0.003)$ \\
\hline \multirow[t]{2}{*}{ Disaffiliated } & $-0.145^{* *}$ & $-0.145^{* *}$ & $-0.145^{* *}$ & -0.078 & $-0.143^{* *}$ \\
\hline & $(0.059)$ & $(0.059)$ & $(0.059)$ & $(0.068)$ & $(0.061)$ \\
\hline \multirow[t]{2}{*}{ Union rivalry } & 0.003 & 0.002 & 0.002 & 0.001 & 0.002 \\
\hline & $(0.003)$ & $(0.003)$ & $(0.003)$ & $(0.003)$ & $(0.003)$ \\
\hline \multirow[t]{2}{*}{ Ind. size } & $0.026^{* *}$ & $0.026^{* *}$ & $0.025^{* *}$ & $0.033^{* *}$ & $0.052^{* *}$ \\
\hline & $(0.010)$ & $(0.011)$ & $(0.012)$ & $(0.011)$ & $(0.019)$ \\
\hline \multirow[t]{2}{*}{ Ind. conc. } & $0.040^{*}$ & $0.033^{*}$ & $0.032^{*}$ & $0.032^{*}$ & $0.051^{* *}$ \\
\hline & $(0.019)$ & $(0.019)$ & $(0.019)$ & $(0.018)$ & $(0.017)$ \\
\hline \multirow[t]{2}{*}{ Unit size } & $-0.166^{* * *}$ & $-0.168^{* * *}$ & $-0.168^{* * *}$ & $-0.170^{* * *}$ & $-0.169^{* * *}$ \\
\hline & $(0.006)$ & $(0.006)$ & $(0.006)$ & $(0.006)$ & $(0.006)$ \\
\hline \multirow[t]{2}{*}{ Union size } & $0.000^{* * *}$ & $0.000^{* * *}$ & $0.000^{* * *}$ & $0.000^{* *}$ & $0.000^{* * *}$ \\
\hline & $(0.000)$ & $(0.000)$ & $(0.000)$ & $(0.000)$ & $(0.000)$ \\
\hline \multirow[t]{2}{*}{ Right to work } & 0.034 & 0.031 & 0.031 & 0.031 & 0.031 \\
\hline & $(0.021)$ & $(0.021)$ & $(0.021)$ & $(0.022)$ & $(0.021)$ \\
\hline \multirow{2}{*}{ No. drives } & -0.000 & -0.000 & -0.000 & -0.000 & -0.000 \\
\hline & $(0.000)$ & $(0.000)$ & $(0.000)$ & $(0.000)$ & $(0.000)$ \\
\hline Union F.E. & & & & Yes & No \\
\hline Year F.E. & & & & No & Yes \\
\hline \multirow[t]{2}{*}{ Constant } & $0.341^{* * *}$ & $0.297^{* * *}$ & $0.297^{* * *}$ & $0.3^{* * *}$ & $0.405^{* * *}$ \\
\hline & $(0.029)$ & $(0.031)$ & $(0.031)$ & $(0.080)$ & $(0.054)$ \\
\hline $\mathrm{N}$ & 21884 & 21884 & 21884 & 21884 & 21884 \\
\hline LL & -14523 & -14234 & -13977 & -13522 & -13608 \\
\hline Pseudo $R^{2}$ & 0.04 & 0.05 & 0.05 & 0.06 & 0.07 \\
\hline
\end{tabular}

